\title{
Inhibition of 14-3-3/Tau by Hybrid Small-Molecule Peptides Operating via Two Different Binding Modes
}

\author{
Sebastian A. Andrei, ${ }^{\dagger, \# \odot ~ F e m k e ~ A . ~ M e i j e r, ~}{ }^{\dagger}, \#$ João Filipe Neves, ${ }^{\dagger}$ Luc Brunsveld, ${ }^{\dagger}$ Isabelle Landrieu, ${ }^{*, *}$ \\ Christian Ottmann, ${ }^{*},, \S(0)$ and Lech-Gustav Milroy*, ${ }^{*}$
}

${ }^{\dagger}$ Laboratory of Chemical Biology, Department of Biomedical Engineering and Institute for Complex Molecular Systems, Technische Universiteit Eindhoven, Den Dolech 2, 5612 AZ Eindhoven, The Netherlands

${ }^{\ddagger}$ UMR 8576 CNRS-Lille University, 59000 Villeneuve d’Ascq, France

${ }^{\S}$ Department of Chemistry, University of Duisburg-Essen, Universitätsstrasse 7, 45117 Essen, Germany

\section{Supporting Information}

\begin{abstract}
Current molecular hypotheses have not yet delivered marketable treatments for Alzheimer's disease ( $\mathrm{AD})$, arguably due to a lack of understanding of $\mathrm{AD}$ biology and an overreliance on conventional drug modalities. Protein-protein interactions (PPIs) are emerging drug targets, which show promise for the treatment of, e.g., cancer, but are still underexploited for treating neurodegenerative diseases. 14-3-3 binding to phosphorylated Tau is a promising PPI drug target based on its reported destabilizing effect on microtubules, leading to enhanced neurofibrillary tangle formation as a potential cause of $\mathrm{AD}$-related neurodegeneration. Inhibition of 14-3-3/Tau may therefore be neuroprotective. Previously, we

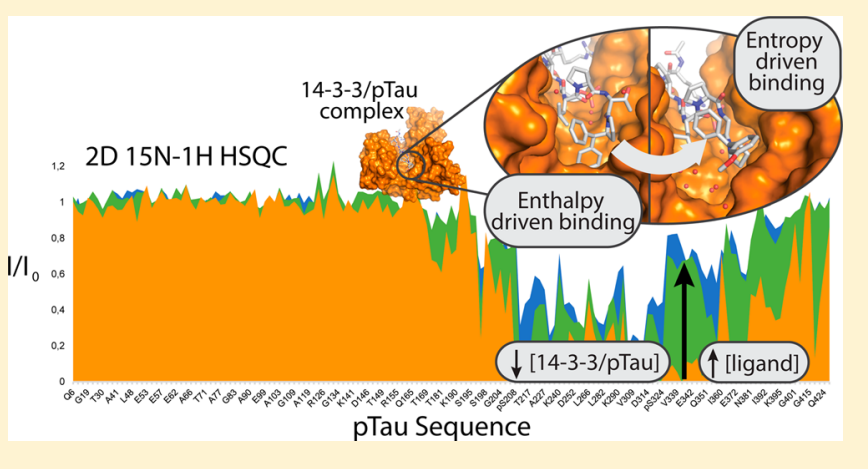
reported the structure-guided development of modified peptide inhibitors of 14-3-3/Tau. Here, we report further efforts to optimize the binding mode and activity of our modified Tau peptides through a combination of chemical synthesis, biochemical assays, and X-ray crystallography. Most notably, we were able to characterize two different high-affinity binding modes, both of which inhibited 14-3-3-binding to full-length PKA-phosphorylated Tau protein in vitro as measured by NMR spectroscopy. Our findings, besides producing useful tool inhibitor compounds for studying 14-3-3/Tau, have enhanced our understanding of the molecular parameters for inhibiting 14-3-3/Tau, which are important milestones toward the establishment of our 14-3-3 PPI hypothesis.
\end{abstract}

KEYWORDS: 14-3-3, tau, protein-protein interactions, inhibitors, drug discovery, peptide chemistry

\section{INTRODUCTION}

Despite the best efforts of academia and pharma, there are currently no marketed drugs for $\mathrm{AD}$. Nonetheless the drug development pipeline of agents to treat the underlying pathology of $\mathrm{AD}$, so-called disease modify therapies (DMTs), is very active, comprising $70 \%$ of the 105 compounds in clinical trials. ${ }^{1}$ While the drug mechanisms of current agents in Phases I-III are heterogeneous, they can nonetheless be broadly classified as targeting either the amyloid cascade or the downstream pathophysiology, including the Tau pathway. Noticeably, more than half of the agents in Phase III are antiamyloids compared to only $4 \%$ directly targeting Tau. ${ }^{1}$ The vast preponderance of all agents in the pipeline is either monoclonal antibodies or $\beta$-site amyloid precursor protein cleaving enzyme (BACE) inhibitors. Given that no treatment has yet been found, there is considerable incentive to address the relatively unexplored Tau pathway. The major one being that, in $\mathrm{AD}$, the severity of cognitive decline is more correlated with the evolution of Tau neurofibrillary tangles (NFTs) than with that of amyloid deposits. ${ }^{2}$ However, the effective targeting of NFTs might require a shift to new molecular modalities, ${ }^{3}$ the solution to which could be found in previously intractable molecular targets. Protein-protein interactions (PPIs) are, by conventional standards, emerging drug targets, ${ }^{4-8}$ which show promise for the treatment of other disease types, such as cancer, ${ }^{9}$ but are as yet underexploited for treating neurodegenerative diseases, including $\mathrm{AD}$, despite the clear potential. ${ }^{10}$ We therefore bring forward the PPI between 14-3-3 proteins and Tau, as a potential therapeutic target to treat $\mathrm{AD} .^{11-13}$

14-3-3 proteins are adapter proteins, existing in seven isoforms, $\beta, \varepsilon, \gamma, \eta, \sigma, \tau$, and $\zeta$, $^{14-16}$ which bind to and modulate the function and folding of phosphorylated proteins. ${ }^{17}$ While abundantly expressed in the body, 14-3-3 proteins are most abundant in CNS compartments. ${ }^{18} 14-3-3$ proteins make important PPIs in diverse pathophysiological settings such as cancer $^{19}$ and metabolic diseases, ${ }^{20}$ and in

Received: March 11, 2018

Accepted: May 3, 2018

Published: May 3, 2018 


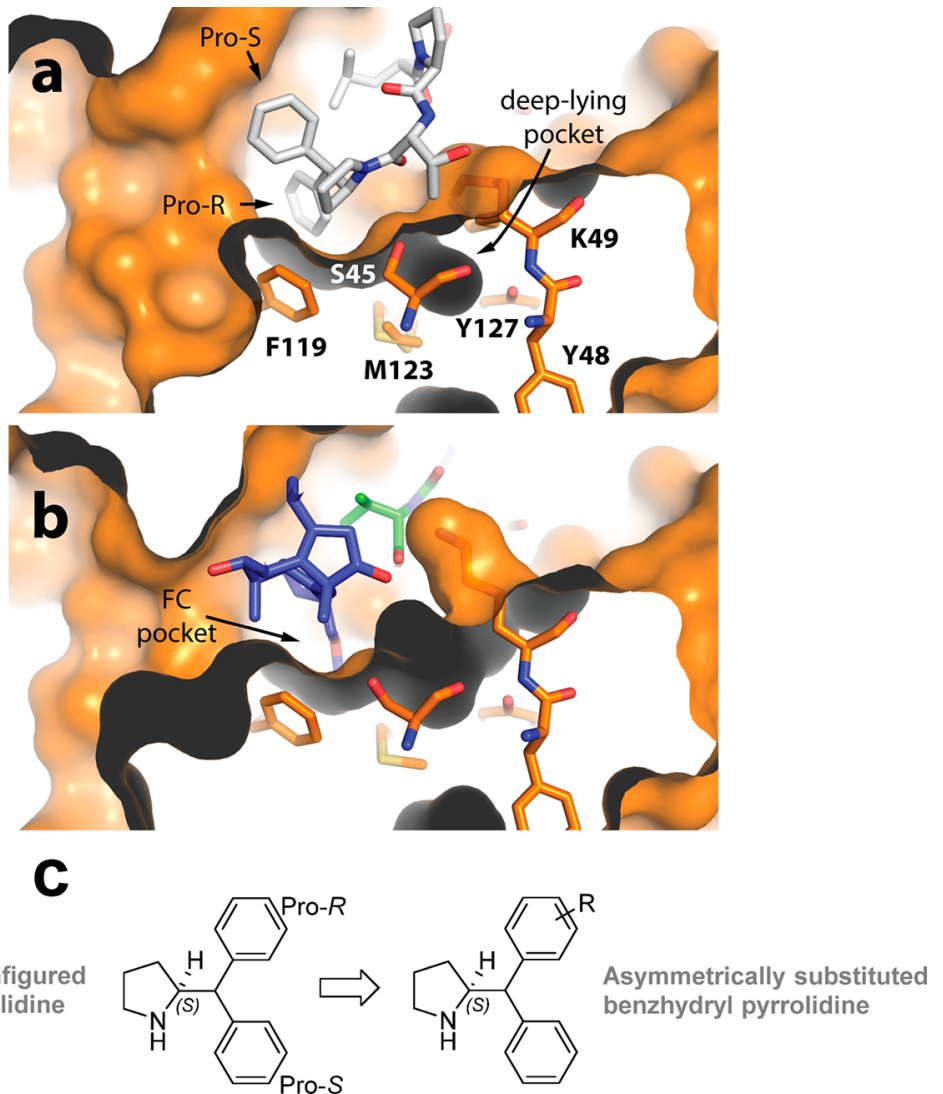

Figure 1. (a) Zoomed in perspective of deep-lying pocket, adjacent to the fusicoccin A (FC) pocket, present in previously published cocrystal structure of a synthetic Tau peptide, modified with a benzhydryl pyrrolidine moiety, bound to 14-3-3 $\sigma \Delta \mathrm{C}$ (PDB: $5 \mathrm{HF} 3$ ). ${ }^{12}$ The modified Tau peptide is depicted in white sticks, the protein surface and residues in orange, and the protein interior surface in dark gray. Pocket-forming amino acid residues are labeled. (b) The same deep-lying pocket present in the ternary complex of 14-3-3 $\sigma \Delta \mathrm{C}$ bound to the C-terminal ER $\alpha$ phospopeptide and FC. The ER $\alpha$ peptide is depicted in green sticks, FC is depicted in blue sticks, the protein surface and residues in orange, and the protein interior surface in dark gray. (c) Chemical structure of symmetric $S$-configured benzhydryl pyrrolidine and general structure of asymmetrically substituted benzhydryl pyrrolidines. Pro- $\mathrm{R}=$ Pro- $\mathrm{R}$ phenyl substituent, Pro- $\mathrm{S}=$ Pro-S phenyl substituent.

neurodegeneration. In the latter case, 14-3-3 proteins bind to a number of client proteins implicated in CNS diseases, among them Tau, $\alpha$-synuclein, parkin, and LRRK2. ${ }^{21}$ Therefore, 14-3-3 proteins are fundamentally interesting targets for neurodegenerative drug therapy, ${ }^{13}$ in which either inhibition or stabilization of 14-3-3 PPIs may prove to be viable therapeutic strategies. $^{22-25}$

Tau protein similarly exerts its multiple neuronal functions by binding a range of partners, the most well-documented being the binding and stabilizing of microtubules. ${ }^{26,27}$ This interaction, as is the case for many Tau interactions, is physiologically regulated by phosphorylation. ${ }^{28}$ However, hyperphosphorylation of Tau, associated with its aggregation inside neurons as paired helical filaments (PHF), are wellknown hallmarks of $\mathrm{AD} .^{29}$ The Tau/14-3-3 association has been found to impact several aspects of the Tau pathway in neurodegeneration. First, $14-3-3 \zeta$ has been described to stimulate Tau phosphorylation by GSK $3 \beta$ kinase in cell model and in brain, ${ }^{30-32}$ and cAMP-dependent protein kinase in vitro. ${ }^{30}$ Additionally, $14-3-3 \zeta$ is reported to be associated with the neurofibrillary tangles composed of Tau PHF in AD brain extracts and to stimulate Tau aggregation in an in vitro assay. $^{33,34}$

Our group has provided X-ray crystallographic evidence for the preferential, bivalent binding of 14-3-3 proteins to phosphoepitope sites, pS214 and pS324, of Tau with affinity in the $\mu \mathrm{M}$ range according to additional biochemical and biophysical data. ${ }^{11}$ We additionally showed that the 14-3-3/Tau interaction could be decreased through 14-3-3 $\sigma$ overexpression in SH-SY5Y cells. ${ }^{11}$ Taken together, these data led us to hypothesize that 14-3-3 binding to phosphorylated Tau (pTau) occurs at the expense of a stabilizing PPI between Tau and microtubules, ${ }^{11}$ which is concomitantly known to be decreased by the phosphorylation of Tau on S214. ${ }^{35}$ Small molecule stabilization of microtubules (MTs) is a promising therapeutic strategy to compensate for the loss of Tau-mediated stabilization. ${ }^{36,37}$ Small molecule inhibition of Tau aggregation, e.g., using cell permeable D-peptides, ${ }^{38}$ may also prove to be a complementary therapeutic strategy. Alternatively, inhibition of 14-3-3/Tau, e.g., through the targeted development of modified peptide inhibitors, could potentially exert a neuroprotective effect by decreasing its phosphorylation level, while increasing the pool of soluble Tau protein for the stabilization of microtubules and by preventing its aggregation, the 14-3-3 PPI hypothesis.

Toward testing our 14-3-3 PPI hypothesis, we previously demonstrated the potential to inhibit 14-3-3/Tau in vitro, with small molecules developed using a structure-guided approach. ${ }^{12}$ With the Tau-derived pS214 phosphopeptide epitope as the chemical starting point, we targeted chemical modifications specifically at the fusicoccin (FC) binding site of Mode III 143-3 $\mathrm{PPIs}{ }^{39}$ to produce a potent inhibitor of $14-3-3 \zeta$ binding to 
full-length (fl)-pTau. In this paper, we report the results of studies in which we attempt structure-guided optimization of our Tau-derived 14-3-3 inhibitors. Most notably we were able to improve the activity of the lead compound from our previous study, and characterize two distinct high affinity modes of interaction by fluorescence polarization (FP) and isothermal calorimetry (ITC) measurements, which we correlate to an "open" and "closed" state based on seven new X-ray cocrystal structures. Both binding modes were shown to inhibit the binding of $14-3-3 \zeta$ to fl-pTau in a concentration-dependent manner, lending further weight to our 14-3-3 PPI hypothesis.

\section{RESULTS AND DISCUSSION}

Rational Design of New 14-3-3 Inhibitors. In a previous study, ${ }^{8}$ we discovered that a synthetic derivative of a pS214-Tau peptide epitope modified at the C-terminus with a benzhydryl pyrrolidine moiety bound more strongly to the 14-3-3 protein than the unmodified Tau epitope. In the resulting crystal structure, the benzhydryl moiety, specifically, the pro- $R$ phenyl ring, can be seen to occupy the fusicoccin (FC) pocket (Figure 1a), thus explaining the improved activity observed in the biochemical and biophysical assays. Closer inspection of the FC pocket identified a deep-lying pocket proximal to the pro- $R$ phenyl group lined by seven amino acid residues derived from the same 14-3-3 protomer: Ser45, Tyr48, Lys49, Phe119, Lys122, Met123, and Tyr 127 (Figure 1a). Interestingly, a similar pocket is also present in other 14-3-3 protein-ligand crystal structure complexes (e.g., the 14-3-3-ER $\alpha$ complexed stabilized by FC, Figure 1b). ${ }^{22}$ The ortho and meta positions of the pro- $R$ phenyl ring are located closest to the deep-lying pocket (Figure 1a). Based on these observations, we hypothesized that the affinity of our modified peptides might be further improved through structural variation of the benzhydryl pyrrolidine group, potentially addressing the deeplying pocket in the process (Figure 1c). We therefore targeted the synthesis of a structurally diverse collection of monosubstituted benzhydryl pyrrolidine analogues (Tables 1-3), in which the phenyl substituent group differed in size and the polarity (i.e., $\mathrm{H} \rightarrow \mathrm{Cl} \rightarrow \mathrm{Me} \rightarrow \mathrm{OMe} \rightarrow \mathrm{OCH}_{2} \mathrm{CH}_{2} \mathrm{OCH}_{3}$, see Table 1).

Synthesis of Substituted Benzhydryl Pyrrolidine Derivatives. The synthesis of asymmetrically substituted benzhydryl pyrrolidine derivatives belonging to the generic structure depicted in Figure 1c was complicated by the absence of any literature precedent. Therefore, we elected for a synthesis based on the stereoretentive synthesis of symmetrically substituted (S)-2-diphenylmethylpyrrolidine (Scheme $1),{ }^{40}$ starting from enantiopure L-proline ester, though cognizant of the lack of obvious stereocontrol in the formation of the asymmetric center at the benzhydryl carbon, and therefore the likely formation of diastereomers.

In brief, the addition of phenylmagnesium bromide to commercial Weinreb amide 2.1, followed by acid workup produced benzoylpyrrolidine $\mathbf{2 . 2}$ in a $47 \%$ yield over the two steps (Scheme 1). Deprotection of the Boc group yielded the substituted pyrrolidine $\mathbf{2 . 3}$, which was followed by protection of the amine group as the ethyl carbamate 2.4. At this juncture, treatment of $\mathbf{2 . 4}$ with a range of structurally diverse substituted Grignard reagents (Table 1) produced a small library of pyrrolooxazolones $\mathbf{2 . 5 a}-\mathrm{g}$, in isolated yields ranging from 25 to $86 \%$. The Grignard reagents used to make pyrrolooxazolones 2.5c and 2.5d are derived from 1-bromo-2-(2-methoxyethoxy)benzene and 1-bromo-3-(2-methoxyethoxy)benzene, respec-
Table 1. Summary of Structures, Yields, and Diastereomeric Ratios (dr) for Pyrrolooxazolone $(2.5 \mathrm{a}-\mathrm{g})$ and Benzhydryl Derivatives $(2.6 \mathrm{a}-\mathrm{g})$ Described in Scheme 1

\begin{tabular}{|c|c|c|c|c|c|c|}
\hline \multirow{3}{*}{ Derivative } & \multirow{3}{*}{$\begin{array}{l}\text { Substituent } \\
\text { group }\end{array}$} & \multicolumn{2}{|l|}{2.5} & \multicolumn{3}{|c|}{2.6} \\
\hline & & \multirow[t]{2}{*}{ yield $^{\%}$} & \multirow[t]{2}{*}{$\mathrm{dr}$} & \multicolumn{2}{|c|}{$\begin{array}{c}\% \\
\text { yield }^{[a]}\end{array}$} & \multirow[t]{2}{*}{$\mathrm{dr}^{[\mathrm{b}]}$} \\
\hline & & & & I & II & \\
\hline $\mathbf{a}$ & & 86 & - & 77 & & $63: 37$ \\
\hline b & & 41 & - & 59 & & $76: 24$ \\
\hline c & & 57 & - & 4 & 44 & $74: 26^{[\mathrm{d}]}$ \\
\hline d & & 80 & - & 55 & 16 & $72: 28^{[\mathrm{d}]}$ \\
\hline e & & 32 & - & 17 & 28 & $63: 37^{[\mathrm{d}]}$ \\
\hline $\mathbf{f}$ & & 25 & - & 26 & 7 & $86: 14^{[\mathrm{d}]}$ \\
\hline g & & 86 & - & 81 & [c] & $66: 34$ \\
\hline
\end{tabular}

${ }^{a}$ Isolated yields of diastereomers either combined or separated by RPHPLC (denoted I or II). ${ }^{b} \mathrm{dr}$ determined by comparing integral values in ${ }^{1} \mathrm{H}$ NMR of crude. ${ }^{c}$ Inseparable diastereomers. ${ }^{d}$ Diastereomers separable by RP-HPLC (Supporting Information).

tively, which could be themselves prepared in one step from commercial compounds (Supporting Information). Pyrrolooxazolones $2.5 \mathrm{a}-\mathrm{g}$ were converted to the corresponding asymmetrically substituted benzhydryl pyrrolidines $\mathbf{2 . 6 a}-\mathbf{g}$ using palladium catalyzed hydrogenation conditions, a step which had been shown to occur without loss of steropurity for the synthesis of $(S)$-2-diphenylmethylpyrrolidine, as evidenced by chiral HPLC and X-ray analysis. ${ }^{40}$ For the series $\mathbf{2 . 5 a - g}$, we were unable to detect more than one diastereomer by either NMR or LC-MS. For the series $\mathbf{2 . 6 a}-\mathbf{g}$ by contrast, analogues $2.6 c-f$ yielded diastereomers, which were separable by reversephase (RP) HPLC, with combined yields in the range of 33$71 \%$ and diastereomeric ratios (drs) in the range 63:37-86:14 (Table 1). We were unable to separate the diastereomers formed in the case of analogues 2.6a, 2.6b, and $2.6 \mathrm{~g}$.

Synthesis of the First Library of Modified Tau Peptides. With the library of asymmetrically substituted pyrrolidine derivatives in hand, we proceeded with the synthesis of the corresponding modified Tau peptides. The synthesis of 3.2a has been described in a previous communication. ${ }^{12}$ The appearance of the $R$-epimer in the cocrystal structure of $3.2 \mathrm{a}$ with 14-3-3 $\sigma$, likely caused by racemization of the threonine $\alpha$ stereocenter during the synthesis, was unexpected because the $S$-epimer was observed to bind $14-3-3 \sigma$ in cocrystal structures for analogous structures reported in the same study, prepared using the same synthetic strategy. ${ }^{12}$ An inspection of all structural data, superposed, suggested that the bulky benzhydryl moiety disfavors binding of the $S$-epimer of $3.2 \mathrm{a}$ through a steric clash between the benzhydryl group and the threonine side chain residue (an effect presumably absent in the case of the $R$-epimer). To test this hypothesis, and specifically probe the steric and stereochemical preferences of the modified Tau peptides for 14-3-3 binding, we synthesized a library of analogous modified Tau peptides in which the C-terminal LThr (3.2a) had been systematically replaced by either Gly 
Scheme 1. Synthesis of Asymmetrically Substituted Benzhydryl Pyrrolidine Derivatives 2.6a-g (Table 1)

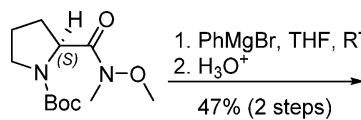

2.1

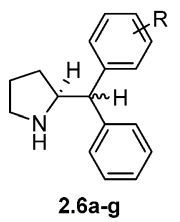

(Table 1)<smiles>O=C(c1ccccc1)C1CCCN1C(=O)c1ccccc1</smiles>

2.2
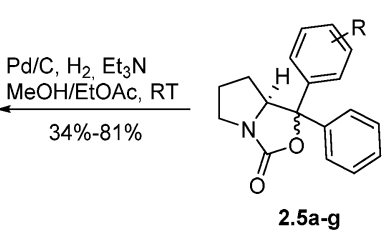
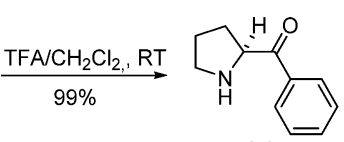

2.3

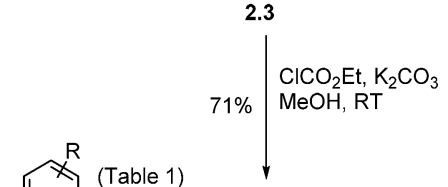

(Table 1)

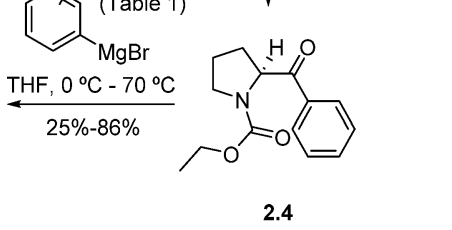

Scheme 2. Synthesis of Modified Tau Peptides 3.2a-f (Table 2) and 4.2a-g (Table 3) ${ }^{a}$
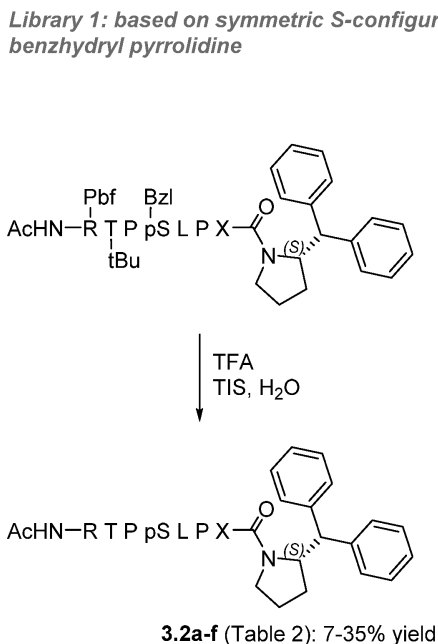

Library 2: based on asymmetric benzhydryl

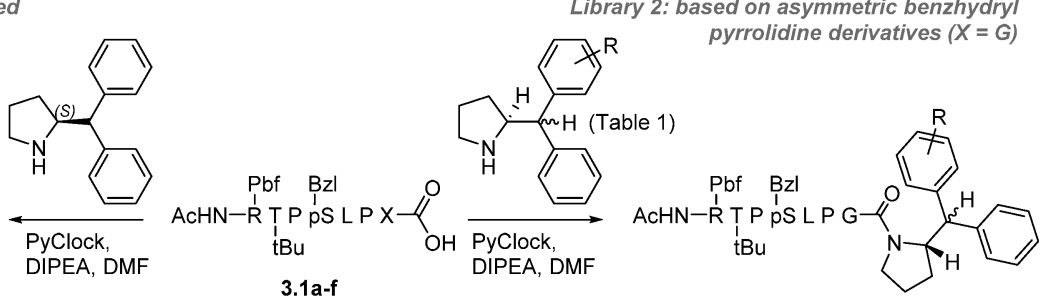

3.1a-f

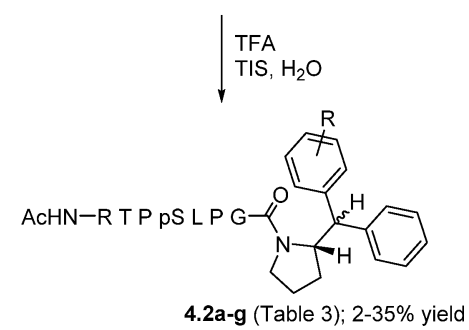

${ }^{a}$ For the synthesis of 3.2a-f, X = L-Thr (3.2a), Gly (3.2b), L-Ala (3.2c), D-Ala (3.2d), L-Val (3.2e), D-Val (3.2f); see Table 2. For the synthesis of 4.2a-g, $\mathrm{R}=$ see Table 3 .

(3.2b) or a short series of other $S$ - and $R$-configured natural amino acid residues with different side chains, L-Ala (3.2c), DAla (3.2d), L-Val (3.2e), and D-Val (3.2f); Scheme 2.

Partially protected Tau peptides $3.1 \mathrm{a}-\mathbf{f}$ were first synthesized as described for a previous synthesis of 3.1a (referred to as $\mathbf{3 b}$ in ref 12) and characterized by LC-MS analysis (Supporting Information). Each partially protected peptide was then coupled to $(S)$-benzhydryl pyrrolidine using PyClock as coupling reagent followed by resin cleavage and deprotection of the side-chain protecting groups (TFA, TIS, $\mathrm{H}_{2} \mathrm{O}$ ) to afford $3.2 \mathrm{a}-\mathrm{f}$ in yields of $8-36 \%$ after purification by RP-HPLC (Scheme 2). While we could not conclusively exclude the possibility of diastereomer impurities in the final compounds, all modified Tau peptides were purified by RP-HPLC on an optimized gradient (see Methods). Please refer to the Supporting Information for LC-MS spectra of all compounds after purification.

Biochemical Evaluation of First Library of Modified Tau Peptides. We next investigated the activity of our first library of modified Tau peptides in a competitive FP assay (Table 2 and Figure S34) and compared their activities to that of our reference compound, 3.2a. The FP data shows that under the specific assay conditions used, all new modified
Table 2. Summary of Structures, and Associated IC $_{50}$ (FP), and $K_{d}$ values for the Modified Tau Peptides 3.2a-f, the Synthesis of Which Is Described in Scheme $2^{a}$

\begin{tabular}{|c|c|c|c|c|c|}
\hline \multirow[b]{2}{*}{ derivative } & \multirow[b]{2}{*}{$\begin{array}{l}\text { amino acid residue, } \\
\text { X (Scheme 2) }\end{array}$} & \multicolumn{2}{|c|}{ FP } & \multicolumn{2}{|c|}{ ITC } \\
\hline & & $\mathrm{IC}_{50} / \mu \mathrm{M}$ & $95 \%$ CI & $K_{\mathrm{d}} / \mu \mathrm{M}$ & $\pm \mathrm{SE}$ \\
\hline $3.2 \mathrm{a}$ & L-Thr & 8.1 & $7.3-8.9$ & 5.4 & 0.4 \\
\hline $3.2 \mathrm{~b}$ & Gly & 5.9 & $5.2-6.8$ & 5.6 & 0.5 \\
\hline $3.2 \mathrm{c}$ & L-Ala & 5.3 & $4.7-5.8$ & 3.3 & 0.7 \\
\hline $3.2 \mathrm{~d}$ & D-Ala & 6.2 & $5.8-6.6$ & 3.0 & 0.6 \\
\hline $3.2 \mathrm{e}$ & L-Val & 6.2 & $5.8-6.5$ & 2.2 & 0.7 \\
\hline $3.2 \mathrm{f}$ & D-val & 7.6 & $7.2-8.1$ & 3.4 & 0.6 \\
\hline
\end{tabular}

${ }^{a_{T}}$ The confidence interval $(\mathrm{CI})$ and \pm standard error $(\mathrm{SE})$ are reported.

peptides $(3.2 \mathbf{b}-\mathbf{f})$ inhibit binding of the competitor FAMlabeled diphosphorylated Tau competitor peptide to $14-3-3 \zeta$, with $\mathrm{IC}_{50}$ values in the same low micromolar range as the reference, 3.2a (Table 2).

ITC measurements were next performed in duplicate on modified Tau peptides 3.2a-f to determine their association constant $\left(\mathrm{K}_{\mathrm{a}}\right)$, stoichiometry $(\mathrm{N})$, and enthalpy $(\Delta H)$ and entropy change $(\Delta S)$ on binding to 14-3-3 (Supporting 
Information). Although the two sets of duplicate measurements are consistent with one another, one set of data are used here for a quantitative comparison of the different analogues. Collectively, the calculated $K_{\mathrm{d}}$ values for analogues $3.2 \mathrm{a}-\mathbf{f}$ (Table 2) are of the same magnitude as the $\mathrm{IC}_{50}$ values determined by FP. The stoichiometries of binding $(N)$ are also all approximately 1.0, which indicates a 1:1 binding between modified peptide and protein. Individually, the $K_{\mathrm{d}}(2.2-5.6$ $\mu \mathrm{M})$ and $\Delta G\left(-7.5\right.$ to $\left.-8.1 \mathrm{kcal} \mathrm{mol}^{-1}\right)$ values for each modified peptide are also very similar across the series, which indicates that they all bind with similar affinity to 14-3-3. In the two cases where the activities of $\mathrm{L}^{-}$and $\mathrm{D}$-isomers could be directly compared, for Ala and Val analogues, similar binding data was measured, e.g., compare the data for the L-Ala analogue, $3.2 \mathrm{c}\left(K_{\mathrm{d}}=3.3 \mu \mathrm{M}, \Delta G=-7.8 \mathrm{kcal} \mathrm{mol}^{-1}\right)$, and the D-Ala analogue, $3.2 \mathrm{~d}\left(K_{\mathrm{d}}=3.0 \mu \mathrm{M}, \Delta G=-7.8 \mathrm{kcal} \mathrm{mol}^{-1}\right)$. There is additional evidence that increasing sterics and hydrophobicity at the $\mathrm{C}$-terminal amino acid produce marginal gains in activity in the series Gly/3.2b $\left(K_{\mathrm{d}}=5.6 \mu \mathrm{M}, \Delta G=\right.$ $\left.-7.5 \mathrm{kcal} \mathrm{mol}^{-1}\right) \rightarrow \mathrm{L}-\mathrm{Ala} / 3.2 \mathrm{c}\left(K_{\mathrm{d}}=3.3 \mu \mathrm{M}, \Delta G=-7.8 \mathrm{kcal}\right.$ $\left.\mathrm{mol}^{-1}\right) \rightarrow \mathrm{L}-\mathrm{Val} / 3.2 \mathrm{e}\left(K_{\mathrm{d}}=2.2 \mu \mathrm{M}, \Delta G=-8.1 \mathrm{kcal} \mathrm{mol}^{-1}\right)$. The thermodynamic binding parameters, $\Delta H$ and $-T \Delta S$, are also similar for all Tau peptide inhibitors in this library (Supporting Information), with the $\Delta H$ value in the range -1.7 to $-2.5 \mathrm{kcal} \mathrm{mol}^{-1}$, and the $\mathrm{T} \Delta S$ value in the range 5.0-6.6 $\mathrm{kcal} \mathrm{mol}^{-1}$. Notably, the $K_{\mathrm{d}} \Delta H, T \Delta S$, and $\Delta G$ values are near identical bearing either threonine $(3.2 \mathrm{a})$ or glycine $(3.2 \mathrm{~b})$ at the C-terminus of the modified Tau peptide. Collectively, the similar FP and ITC data imply that the analogues $3.2 \mathrm{a}-\mathrm{f}$ are binding to 14-3-3 with a similar binding mode, the hypothesis being that the benzhydryl group in each case binds the FC pocket in a mode similar to the one observed in the crystal structure for 3.2a (Figure 1a). ${ }^{12}$ Furthermore, increasing the steric bulk and hydrophobicity produces a marginal increase in activity, while inverting the stereochemistry of the C-terminal amino acid residue importantly has no significant effect on the modified Tau peptide's binding and inhibitory properties.

Synthesis of the Second Library of Modified Tau Peptides. In view of the measured equipotency and similar thermodynamic profiles of the L-Thr (3.2a) and Gly analogues (3.2b), we elected to prepare a second library of modified Tau peptides based on $\mathbf{3 . 2 b}$. We reasoned that replacing L-Thr with Gly would simplify the synthesis while retaining the ability to explore the FC pocket, potentially addressing the adjacent deep-lying pocket (Figure 1a) through the introduction of asymmetrically substituted benzhydryl pyrrolidine derivatives. A second library of modified Tau peptides, $4.2 \mathrm{a}-\mathrm{g}$, was therefore synthesized, of which the details are outlined in Scheme 2 and the structures summarized in Table 3. For some of the derivatives, two diastereomers were separated by RP-HPLC, denoted I and II, in yields of between 3 and $32 \%$ for the individual diastereomers, and overall combined isolated yields of between 34 and 57\% (see Methods).

Biochemical Evaluation of Second Library of Modified Tau Peptides. As for the first library, we used FP and ITC to characterize the 14-3-3 binding properties of our second library of modified Tau peptides. The findings of this short study are summarized in Table 3. The FP data (Figure S35) shows that all analogues from this library function as competitive inhibitors of $14-3-3 \sigma$ with $\mathrm{IC}_{50}$ values in the range $2.8-12.1 \mu \mathrm{M}$. Our ITC data show that all analogues bind to $14-3-3 \sigma$ with $K_{\mathrm{d}}$ values in the range $2.7-20.6 \mu \mathrm{M}$ and $\Delta G$ values between -6.7 and -7.9 $\mathrm{kcal} \mathrm{mol}^{-1}$. The most active analogue in the series was the 2-
Table 3. Summary of Structures, and Associated IC $_{50}$ (FP), and $K_{\mathrm{d}}$ Values for the Modified Tau Peptides 4.2a-g Described in Scheme $3^{b}$

\begin{tabular}{|c|c|c|c|c|c|}
\hline \multirow[b]{2}{*}{ Derivative } & \multirow{2}{*}{$\begin{array}{l}\text { Substituent } \\
\text { group }\end{array}$} & \multicolumn{2}{|c|}{ FP } & \multicolumn{2}{|c|}{ ITC } \\
\hline & & $\begin{array}{c}\mathrm{IC}_{50} / \\
\mu \mathrm{M}\end{array}$ & $\begin{array}{c}95 \% \\
\text { CI }\end{array}$ & $\begin{array}{l}\mathrm{K}_{\mathrm{d}} / \\
\mu \mathrm{M}\end{array}$ & $\begin{array}{l}( \pm \\
\text { SE) }\end{array}$ \\
\hline $4.2 \mathrm{a}^{[\mathrm{a}]}$ & & 6.0 & $5.7-6.5$ & 8.9 & 0.7 \\
\hline $4.2 b^{[a]}$ & & 5.9 & $5.6-6.3$ & 9.3 & 2.0 \\
\hline $4.2 \mathrm{c}-\mathrm{I}$ & & 2.8 & $2.2-3.6$ & 2.7 & 0.3 \\
\hline $4.2 \mathrm{c}-\mathrm{II}$ & & 4.2 & $4.0-4.5$ & 9.0 & 0.5 \\
\hline $4.2 \mathrm{~d}-\mathrm{I}$ & & 5.5 & $5.0-6.1$ & 6.3 & 0.6 \\
\hline $4.2 \mathrm{~d}-\mathrm{II}$ & & 12.1 & $\begin{array}{l}10.7- \\
13.7\end{array}$ & 20.6 & 2.4 \\
\hline $4.2 \mathrm{e}-\mathrm{I}$ & & 5.0 & $4.8-5.3$ & 3.6 & 0.6 \\
\hline $4.2 \mathrm{e}-\mathrm{II}$ & & 10.4 & $\begin{array}{l}9.6- \\
11.2\end{array}$ & 12.7 & 0.9 \\
\hline $4.2 \mathrm{f}-\mathrm{I}$ & & 5.8 & $5.5-6.0$ & 4.7 & 0.6 \\
\hline $4.2 \mathrm{f}-\mathrm{II}$ & & 11.4 & $\begin{array}{c}10.7- \\
12.2\end{array}$ & 16.5 & 2.0 \\
\hline $4.2 \mathrm{~g}^{[\mathrm{a}]}$ & & 7.2 & $6.5-7.8$ & 6.2 & 1.2 \\
\hline $3.2 \mathrm{~b}$ & & 5.9 & $5.2-6.8$ & 5.6 & 0.5 \\
\hline
\end{tabular}

${ }^{a} \mathrm{~A}$ mixture of diastereomers. ${ }^{b}$ The confidence interval (CI) and \pm standard error (SE) are reported.

(methoxyethoxy)- derived 4.2c-I $\left(K_{\mathrm{d}}=2.7 \mu \mathrm{M} / \Delta G=-7.9\right.$ $\left.\mathrm{kcal} \mathrm{mol}^{-1}\right)$ and the least active, its regioisomer, analogue $4.2 \mathrm{~d}$ II $\left(K_{\mathrm{d}}=20.6 \mu \mathrm{M} / \Delta G=-6.7 \mathrm{kcal} \mathrm{mol}^{-1}\right)$. Besides $4.2 \mathrm{c}-\mathrm{I}$, analogue 4.2e-I $\left(K_{\mathrm{d}}=3.6 \mu \mathrm{M} / \Delta G=-7.7 \mathrm{kcal} \mathrm{mol}^{-1}\right)$ and methoxy-derivative 4.2f-I $\left(K_{\mathrm{d}}=4.7 \mu \mathrm{M} / \Delta G=-7.5 \mathrm{kcal}\right.$ $\mathrm{mol}^{-1}$ ) were also strong binders.

X-ray Crystallography Studies. To provide a molecular explanation for the high affinity binding of our new modified tau peptide inhibitors, the cocrystal structures of symmetrically substituted benzhydryl derivatives, $3.2 \mathrm{~d}(1.70 \AA)$, and 3.2e $(2.00 \AA)$, and asymmetrically substituted variants $4.2 b$ (1.50 $)$, 4.2c-I (1.40 $\AA$ ), 4.2e-I (1.25 $\AA), 4.2 \mathrm{f}-\mathrm{I}(1.40 \AA)$ and 4.2f-II $(1.45 \AA)$ bound to $14-3-3 \sigma \Delta \mathrm{C}$ were solved to their respective resolutions in parentheses (Figure 2 and Supporting Information). Figure $2 \mathrm{a}$ depicts a superimposition of the three modified Tau peptides, 3.2a (white), ${ }^{12} 3.2 \mathrm{~d}$ (purple), and 4.f-II (green), in their 14-3-3-bound state, in which all three peptides clearly bind with a similar extended mode within the amphipathic groove of the protein. However, the structural differences between the three peptides at the C-terminus is observed to perturb the positioning of the peptide backbone and the leucine side-chain C-terminal to the phosphoserine residue. This general trend is representative for all cocrystallized modified Tau peptides. In Figures $2 \mathrm{~B}-\mathrm{I}$, a panel comparing zoomed-in perspectives of the FC pocket of the seven different cocrystallized modified Tau peptides can be 


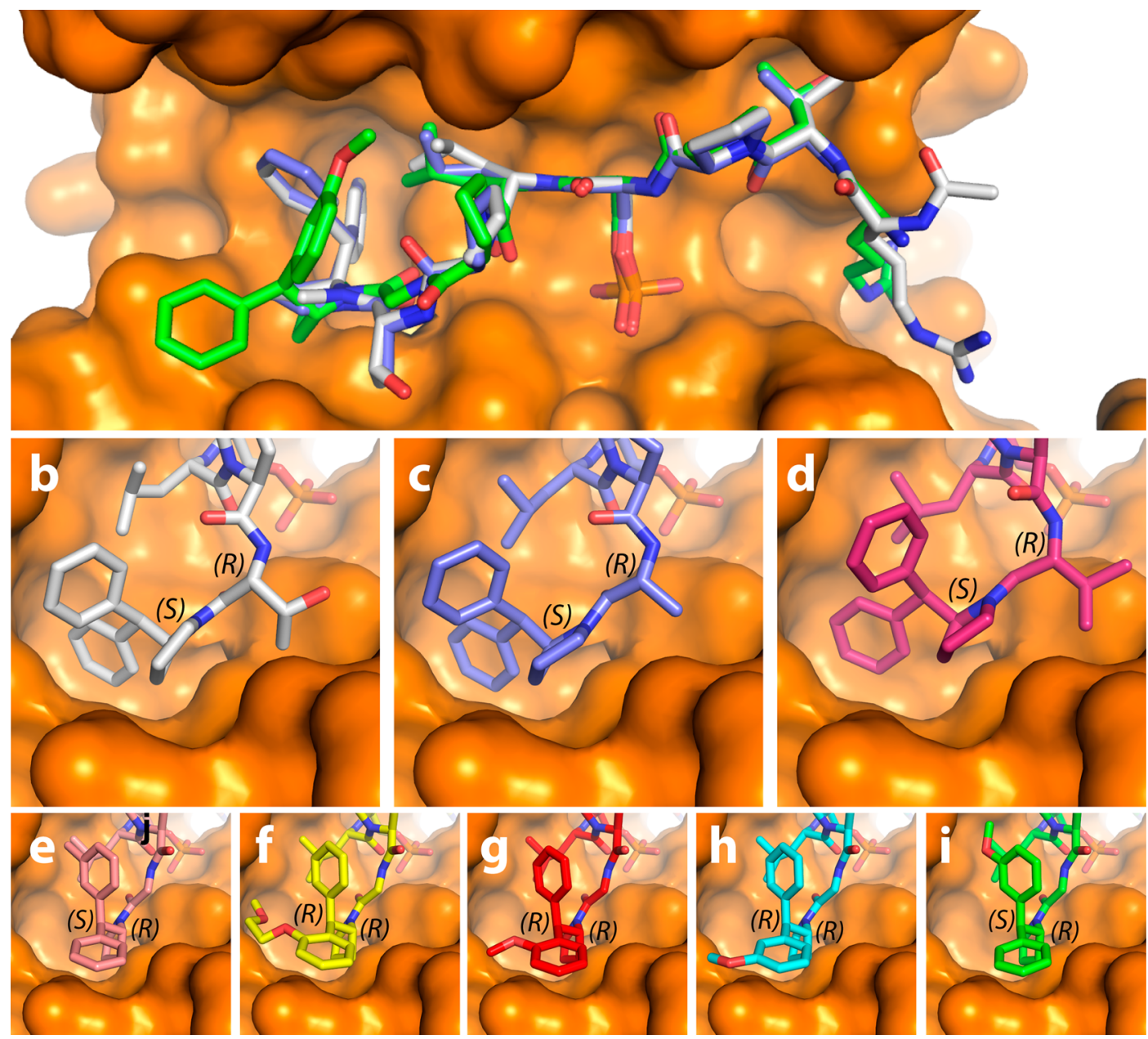

Figure 2. (a) Overlay of the cocrystal structures of the modified peptides 3.2a (white) (PDB: 5HF3) ${ }^{12}$ 3.2d (purple) (PDB: 6FI5), and 4.2f-II (green) (PDB: 6FBW) bound to 14-3-3 $\sigma \Delta \mathrm{C}$. (b-i) Zoom-in of FC pocket for the cocrystal structures of the modified peptides 3.2a (b) (PDB: $5 \mathrm{HF} 3),{ }^{12}$ 3.2d (c) 3.2e (d) (PDB: 6FI4), 4.2b (e) (PDB: 6FBY), 4.2c-I (f) (PDB: 6FAW), 4.2e-I (g) (PDB: 6FAW), 4.2f-I (h) (PDB: 6FAV), and 4.2f-II (i) bound to $14-3-3 \sigma \Delta$ C. The stereochemical assignment ( $S$ and $R$ notation) of the C-terminal amino acid and benzhydryl pyrrolidine solved in complex with the 14-3-3 protein have been added to each panel.

seen: the two benzhydryl-derived (3.2d and 3.2e) and five asymmetrically substituted analogues $(4.2 \mathrm{~b}, 4.2 \mathrm{c}-\mathrm{I}, 4.2 \mathrm{e}-\mathrm{I}, \mathbf{4 . 2 \mathrm { f }}$ I, and 4.2f-II), compared to 3.2a. In contrast to analogues $3.2 \mathrm{~d}$ and $3.2 \mathrm{e}$, in which the pyrrolidine group were logically determined to be $S$-configured (derived from commercial $(S)$ 2-(diphenylmethyl)pyrrolidine), all five asymmetrically substituted analogues were unexpectedly observed to be $R$ configured at the $\alpha$-carbon of the pyrrolidine ring, counter to our expectations (Figure $2 \mathrm{e}-\mathrm{i}$ ). ${ }^{40}$ Interestingly as well, all of the five peptides modified with an asymmetrically substituted benzhydryl group bound in a similar "open" state, which contrasted with the "closed" state observed in the case of the three symmetric benzhydryl analogues. A closer examination of this data reveals that the oxygen of the methoxy substituent on 4.2f-I (Figure $2 \mathrm{~h}$ ) is sufficiently close $(3.1 \AA)$ to engage in a hydrogen bond with the side chain of residue Asn-42-an interaction witnessed previously between the sugar ring-oxygen of the natural product fusicoccin A (FC) and Asn-42 of 14-3-3 $\sigma$ for stabilization of TASK-3 (PDB: 5D3F; $2.7 \AA)^{23}$ and 14-3-3 for stabilization of CFTR (PDB: 3P1Q; $3.2 \AA) .{ }^{41}$ By comparison, an analogous hydrogen bond interaction is absent from the crystal structure of the less potent diastereomer 4.2f-II (Figure 2i). The ITC data for diastereomers 4.2f-I and 4.2f-II indicate that their 2-fold difference in affinity by FP and 3.5-fold difference by ITC is entropically driven (Figure 3 and Table S2 in the Supporting Information). An explanation for the potency of analogue $4.2 \mathrm{c}-\mathrm{I}$, the most potent of the series, can be observed in the crystal structure in which the methoxyethoxy side chain clearly addresses the FC pocket (Figure $2 \mathrm{f}$ ). A more detailed discussion of all the cocrystal structures can be found in the Supporting Information.

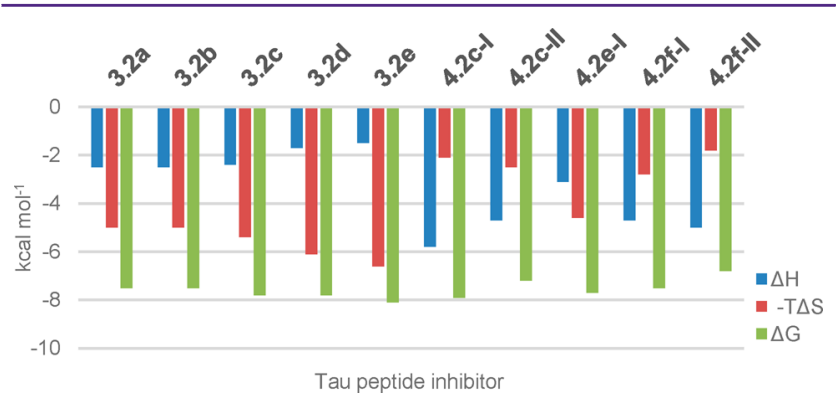

Figure 3. Comparison of enthalpic $(\Delta H$, blue) and entropic contributions $(-\mathrm{T} \Delta S$, red) to the Gibbs free energy of binding $(\Delta G$, green) at $310 \mathrm{~K}$ for modified Tau peptides $3.2 \mathrm{a}, 3.2 \mathrm{~b}, 3.2 \mathrm{e}$, and $4.2 \mathrm{f}-\mathrm{I}$ For a comprehensive comparison of thermodynamic parameters for all modified Tau peptides see the Supporting Information (Table S2). 
Stereochemical Outcome of Modified Tau Peptide Synthesis. Logically, the $R$-configuration of the D-Ala-derived modified Tau peptide was found in the 14-3-3/3.2d cocrystal structure (Figure 2c). Interestingly, the $R$-epimer was also observed in the cocrystal structure of the Val-derived modified Tau peptide 3.2e (Figure 2d), which parallels the result obtained previously ${ }^{12}$ for the L-Thr-derived modified Tau peptide 3.2a (Figure 2a). While the origin of the epimer formation in both cases remains unclear (both syntheses began with enantiomerically pure L-amino acids), it is hypothesized that the $S$-epimer of $\beta$-branched amino acids is sterically less favored for binding at the peptide C-terminus than the corresponding $R$-epimer. Significantly, the introduction of a glycine residue at the same C-terminal position of our peptides, which will not be dependent on epimerization, did not significantly affect the affinity of our modified Tau peptides. The electron densities clearly show that the R-epimer is bound to 14-3-3 for each of the five asymmetrically substituted analogues (4.2b, 4.2c-I, 4.2e-I, 4.2f-I, and 4.2f-II), which was unexpected because the synthesis of the corresponding monosubstituted benzhydryl pyrrolidine in each case commenced with $S$-configured L-proline, and was based on a enantioretentive synthesis of (S)-2-(diphenylmethyl)pyrrolidine. ${ }^{40}$ However, we did not monitor the stereochemical outcome at each step during the synthesis of our monosubstituted benzhydryl pyrrolidine derivatives.

Analysis of Thermodynamic Parameters of Binding. A clear difference was observed between the thermodynamic parameters for the asymmetrically substituted and those measured for the symmetrically substituted benzhydryl pyrrolidine-modified Tau peptides. In the case of the asymmetrically substituted analogues, the enthalpy change $(\Delta H)$ was in general more negative and the entropy change $(-\mathrm{T} \Delta S)$ more positive than for the symmetrically substituted benzhydryl pyrrolidine-modified Tau peptides. For example, while $3.2 \mathrm{e}\left(K_{\mathrm{d}}=2.2 \mu \mathrm{M}, \Delta G=-8.1 \mathrm{kcal}\right)$ and $4.2 \mathrm{f}-\mathrm{I}$ gave similar binding parameters $\left(K_{\mathrm{d}}=4.7 \mu \mathrm{M}, \Delta G=-7.5 \mathrm{kcal}\right.$ $\mathrm{mol}^{-1}$ ), their corresponding thermodynamic components significantly diverge (Figure 4). In the case of $3.2 \mathrm{e}$, the entropic factor $\left(-T \Delta S=-6.6 \mathrm{kcal} \mathrm{mol}^{-1}\right)$ contributed significantly more to the free energy of binding than the enthalpic factor $\left(\Delta H=-1.5 \mathrm{kcal} \mathrm{mol}^{-1}\right)$, while for analogue 4.2f-I, the opposite was true (i.e., $\Delta H=-4.7 \mathrm{kcal} \mathrm{mol}^{-1}$ and $\left.-T \Delta S=-2.8 \mathrm{kcal} \mathrm{mol}^{-1}\right)$. The same divergent behavior was observed across all Tau peptide inhibitors reported in Tables 2
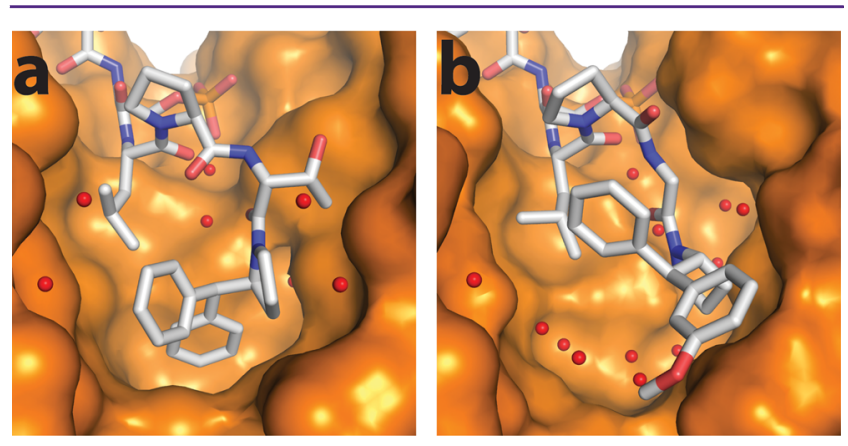

Figure 4. Crystal structure of (a) 3.2a at $1.8 \AA$ resolution (PDB: 5HF3) and (b) 4.2f-I (PDB: 6FAV) at $1.4 \AA$ resolution, in complex with 14-3-3 $\sigma$. A difference in the amount of water molecules (red spheres) in the pocket can be observed, which may explain the difference in entropy observed in the ITC data. and 3 such that compound binding could be classified as being either predominantly entropically driven (i.e., the symmetric benzhydryl analogues $3.2 \mathrm{a}-\mathbf{f}$ ) or enthalpically driven (i.e., the asymmetric analogues $4.2 \mathrm{a}-\mathrm{g}$ ).

A structural explanation for the two classifications of ITC data could be found in the crystallography data (Figure 4). The predominantly entropically driven binding profile characterized by ITC could be explained by the "closed" binding mode characterized by X-ray crystallography (illustrated by $\mathbf{3 . 2 a}$, Figure $4 a$ ), in which the $S$-configured symmetric benzhydryl moiety is observed to fill the hydrophobic FC-binding pocket better. In this mode, the reduced solvent-exposed hydrophobic surface area results in fewer ordered water molecules (as evidenced in Figure 4a), which drives binding through a gain in entropy. By contrast, the predominantly enthalpically driven binding profile (illustrated by $\mathbf{4 . 2 f - I}$, Figure $4 \mathrm{~b}$ ) could be explained by a more "open" binding mode in the X-ray crystal structure, in which the now $R$-configured asymmetrically substituted benzhydryl moiety is found in a more solventexposed state, which permits the binding of more ordered water molecules (as evidenced in Figure 4b), resulting in a comparatively lower entropic contribution on binding.

A similar correlation between the ITC and the crystallography data for all other solved structures was observed, which suggests that all derivatives bearing the same, either enthalpic or entropic, binding profile by ITC (whether cocrystallized or not with the 14-3-3 protein) bind via the aforedescribed "closed" or "open" binding modes by X-ray crystallography. The reason for the two different binding modes is likely two fold: first, the difference in $R$ and $S$ configuration between the asymmetrically substituted benzhydryl pyrrolidine moieties ( $R$-configured), which all bind in the "open" state, and the $S$-configured symmetric benzhydryl pyrroldines, which bind in the "closed" state. Second, a steric clash between the asymmetrically substituted benzhydryl group and the protein surface may disfavor a "closed" binding mode, which the ligand would relieve by adopting the more "open" binding state. In view of the ITC data for the Gly-derivative $\mathbf{3 . 2 b}$, the suggestion is the benzhydryl group of this derivative binds in a similar "closed" state as observed for e.g. 3.2a, 3.2d, and 3.2e. This result would suggest the added conformational freedom introduced by the C-terminal glycine residue would apparently not significantly influence the binding mode of $\mathbf{3 . 2} \mathbf{b}$, and by extension analogues from within the 4.2 series. While the modifications at the $\mathrm{C}$ terminus of our modified Tau peptides do not address the targeted deep-lying pocket of the 14-3-3 protein (Figure 1C), as hypothesized, they have enabled the potent targeting of chemically distinct sites within the adjacent FC pocket.

Inhibition of the Interaction of 14-3-3 with FullLength Phosphorylated Tau Protein. We next investigated the potential of the three most potent analogues toward the inhibition of the interaction between 14-3-3 $\zeta$ and full-length PKA-phosphorylated Tau (pTau). From the analogues tested, one (3.2e), binds to 14-3-3 via an "open" binding mode, while the other two, (4.2c-I and 4.2e-I), via the "closed" binding mode. NMR spectroscopy was used to assess the modulation of this PPI in solution, using chemical shift perturbation mapping, based on the assigned resonances of the phosphorylated Tau ${ }^{1} \mathrm{H}-{ }^{15} \mathrm{~N} 2 \mathrm{D}$ spectrum. ${ }^{42-45}$ The $2 \mathrm{D}{ }^{15} \mathrm{~N}-{ }^{1} \mathrm{H}$ HSQC spectra of ${ }^{15} \mathrm{~N}$-labeled pTau in the presence of unlabeled $14-3-3 \zeta$ were acquired with or without each of the inhibitors. The intensities of the correlation peaks corresponding to specific amino acid residues along pTau sequence (I) were monitored in each 

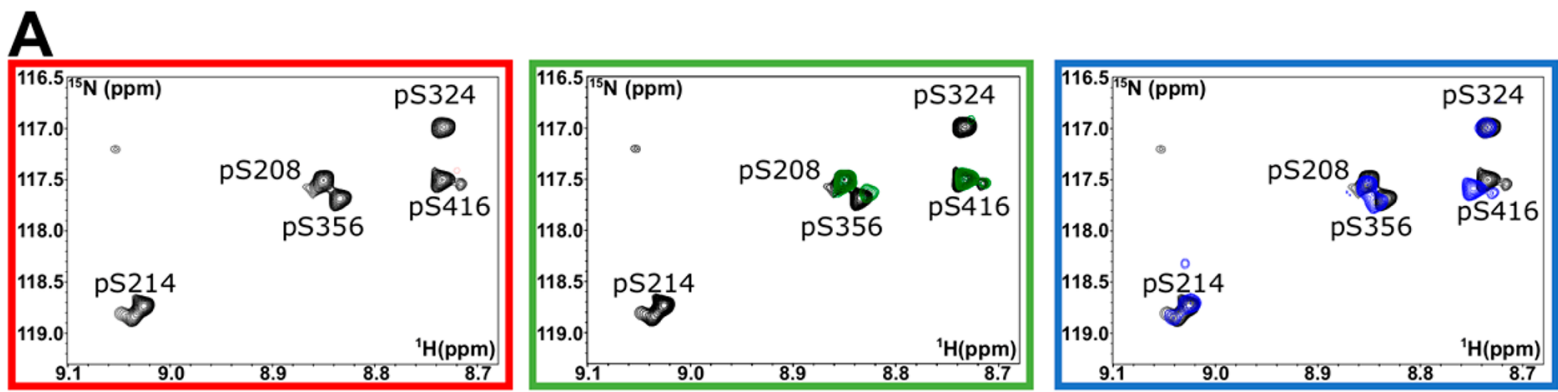

$\mathbf{B}_{1,2} \mathrm{I} / \mathrm{IO}$

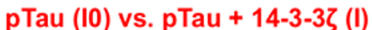

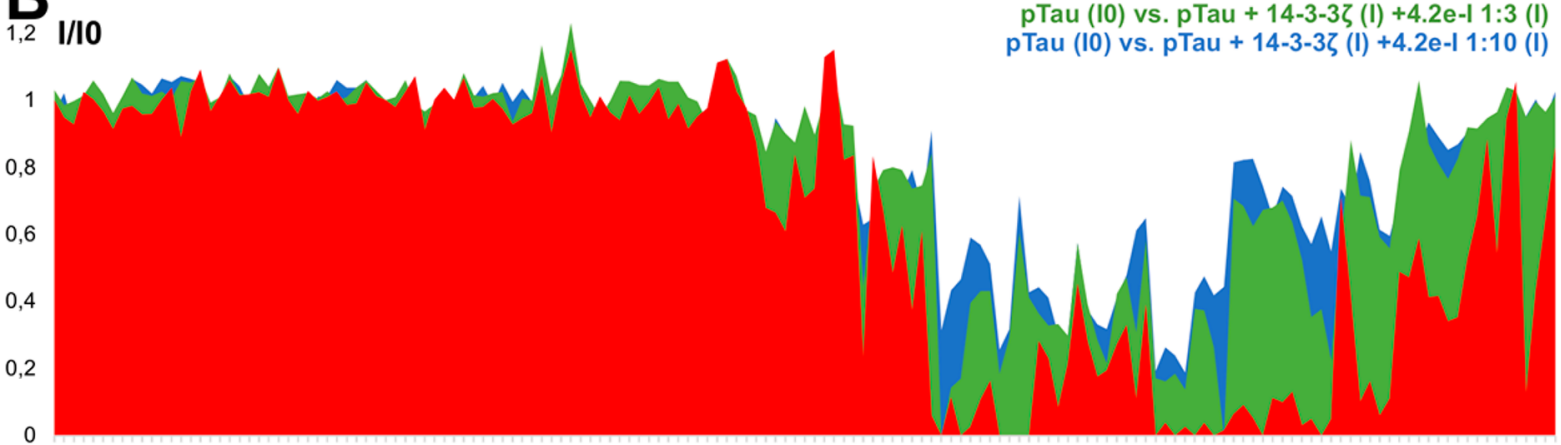

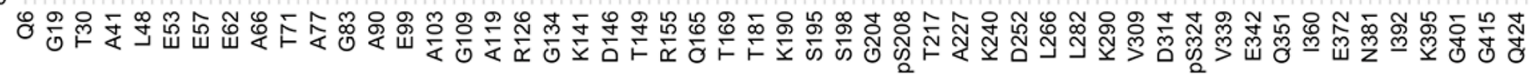

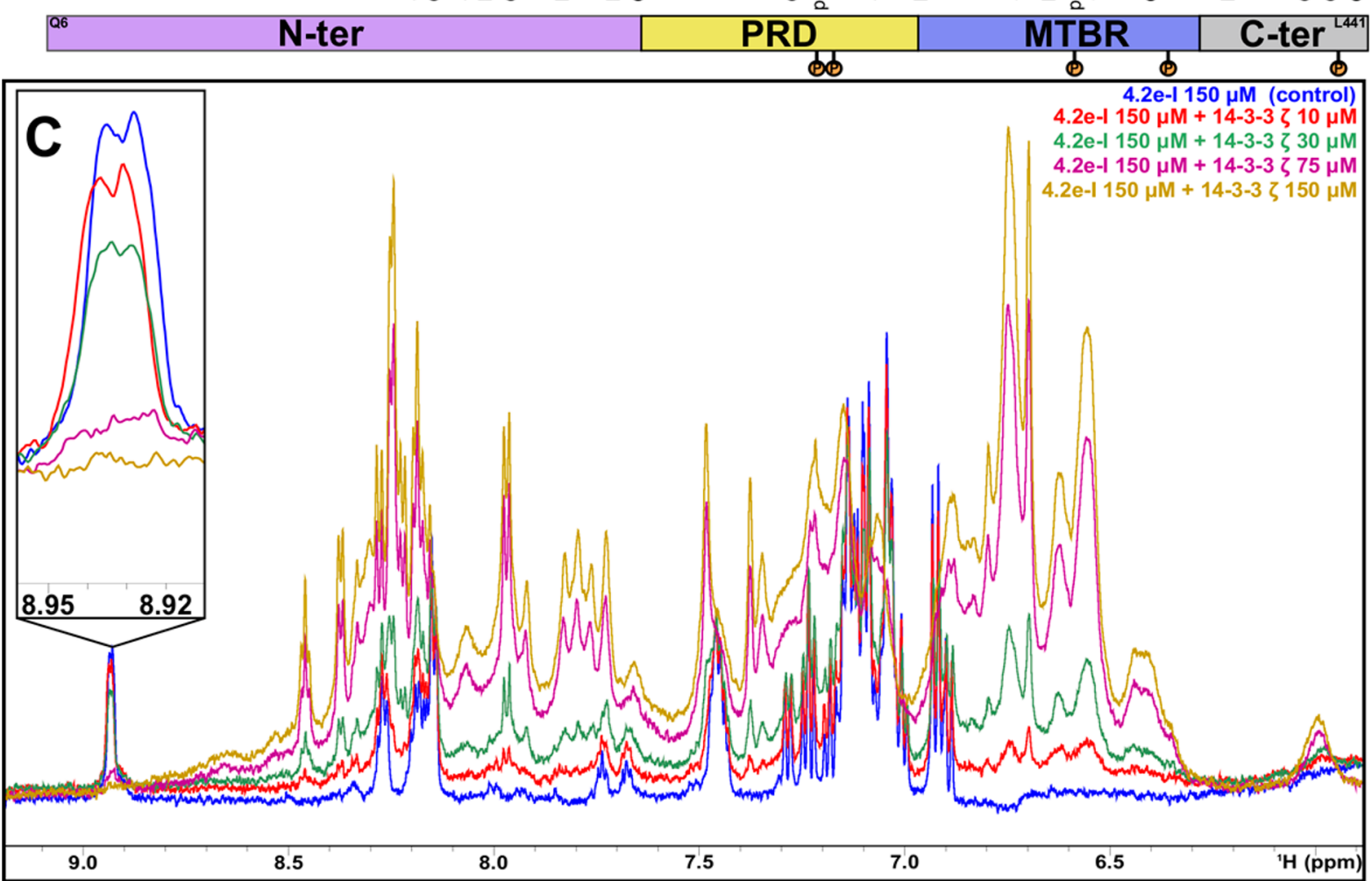

Figure 5. 4.2e-I inhibits the binding of pTau to $14-3-3 \zeta$ in a concentration-dependent manner. (A) Selected enlarged regions of the overlaid ${ }^{1} \mathrm{H}-{ }^{15} \mathrm{~N}$ HSQC spectra showing the intensity recovery of the correlation peaks corresponding to the amide groups of the PKA-phosphorylated Serines after the addition of 4.2e-I. The spectra are shown superimposed to the pTau spectrum, which is colored in black. With the addition of a 3-fold excess of 4.2e-I (considering 14-3-3 $\zeta$ concentration) it is possible to remark the intensity recovery of the weakest epitopes (pS208, pS356 and pS416) and finally, with the addition of a 10 -fold, it is possible to detect pS214 and pS324. (B) Plot of the ratios of the bound (I)/free (I0) ${ }^{1} \mathrm{H}-{ }^{15} \mathrm{~N}$ correlation

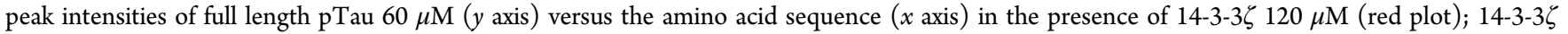

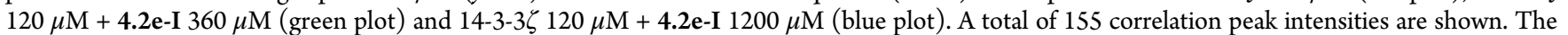
$x$ axis is not proportional. The domains of full-length pTau (N-ter for N-terminal; PRD for Proline-Rich Domain; MTBR for Microtubule Binding Region; C-ter for C-terminal) and the phosphorylation sites (S208, S214, S324, S356, and S416) are identified below the $x$ axis. (C) Section of

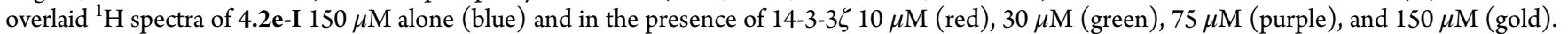
The enlarged region shows a well-isolated resonance corresponding to a 4.2e-I proton. 
experiment and compared to the intensities of the corresponding correlation peaks in the spectrum of pTau alone (I0). The binding of $14-3-3 \zeta$ to pTau led to peak broadening and consequently, to the decrease of the (I/I0) ratio for resonances corresponding specifically to residues located in the binding region of 14-3-3 (Figure 5a and $5 \mathrm{~b}$ ). The addition of 4.2e-I to the solution containing ${ }^{15} \mathrm{~N}$ pTau/14-3-3 $\zeta$ led to a dosedependent recovery of the intensity of these same resonances (Figure 5a and 5b). This effect is well illustrated by the resonances corresponding to the amide groups of the PKAphosphorylated serines of Tau that showed intensity recovery with addition of each analogue (Figures $5 b$ and S36). The same set of $2 \mathrm{D}$ experiments was performed for inhibitors 3.2e and 4.2c-I resulting in a similar I/I0 profile (Figures 5, S37, and S38), which confirmed the capacity of these analogues to decrease the formation of the complex 14-3-3 //pTau. To get further insights on the inhibitory effect of these analogues, a series of ${ }^{1} \mathrm{H}$ spectra of $4.2 \mathrm{e}-\mathrm{I}$ was recorded in the presence of increasing concentrations of 14-3-3 $\zeta$ (Figure 5c). By monitoring one well-isolated resonance of the spectrum of the smallmolecule, a concentration dependent intensity decrease upon the addition of $14-3-3 \zeta$ was observed, which can be attributed to the interaction, as the sharp signal of the free ligand get broadened when complexed with the protein. Additionally, the spectrum of 4.2e-I was recorded in the presence and absence of pTau, which did not reveal any sign of interaction (Figure S39) as both spectra were identical. Based on these results, it can be concluded that 3.2e, 4.2c-I, and 4.2e-I inhibited the interaction $\mathrm{pTau} / 14-3-3 \zeta$ in a concentration dependent manner, by binding to $14-3-3 \zeta$ and competing with pTau.

\section{CONCLUSIONS}

Here, we describe the synthesis of a novel 17-membered collection of modified Tau peptide inhibitors, targeting increased binding affinity at the fusiccocin A (FC) pocket and proximal deep-lying pocket. In the case of the peptides bearing a symmetric, $S$-configured benzhydryl pyrroldine group, exchanging the $\mathrm{C}$-terminal $\mathrm{Thr}$ residue during the synthesis with a number of other $\mathrm{L}$ - and $\mathrm{D}$-amino acid residues at the $\mathrm{C}$ terminus of the Tau peptide, including nonchiral Gly, did not produce a significant change in the $\mathrm{IC}_{50}$ and $K_{\mathrm{d}}$ and associated thermodynamic parameters. This result suggested that the $C$ terminal amino acid in the modified Tau peptide can be flexibly replaced by amino acids bearing different side chains and stereochemistry. All resulting Tau peptide analogues (Tables 2 and 3) were active inhibitors of 14-3-3/Tau. Interestingly, using a combination of FP, ITC, and X-ray crystallography data, we characterized two binding modes for our modified Tau peptides: one "closed" entropically driven state, the other an "open" enthalpic state at the peptide C-terminus. The difference between the two binding modes is most likely caused by the inverted stereochemistry at the $\alpha$-carbon between the commercial $S$-configured symmetric benzhydryl pyrrolidine ("closed") and the synthetic R-configured asymmetric benzhydryl pyrrolidine ("open") (an unexpected outcome of the synthesis) and steric factors induced by monosubstitution of the benzhydryl group. While neither of these two modes were capable of addressing the deep-lying pocket (Figure 1c), both inhibited 14-3-3-binding to full-length PKA-phosphorylated Tau protein in vitro. Considering the manner in which the Tau-derived phosphoepitope has been studied presently, it could also be envisaged as a noncovalent tether to investigate new chemotypes to address the FC pocket, thus potentially opening the door to new nonphosphorylated inhibitors or novel stabilizers of Mode III 14-3-3 PPIs.

\section{METHODS}

Synthesis of Substituted Benzhydryl Pyrrolidine Derivatives. General Methods. Unless otherwise stated, all solvents employed were commercially available and used without purification. Water was purified using a Millipore purification train. Dry solvents were obtained from a MBRAUN Solvent Purification System (MBSPS-800). Deuterated solvents were obtained from Cambridge Isotope laboratories. All reagents were commercially available, supplied by Sigma-Aldrich, and used without purification. NMR data were recorded on a Bruker Cryomagnet for NMR spectroscopy (400 $\mathrm{MHz}$ for ${ }^{1} \mathrm{H}$ NMR and $100 \mathrm{MHz}$ for ${ }^{13} \mathrm{C}$ NMR). Proton experiments were reported in parts per million (ppm) downfield of TMS. All ${ }^{13} \mathrm{C}$ spectra were relative to the residual chloroform signal $(77.16 \mathrm{ppm}) .{ }^{1} \mathrm{H}$ NMR spectra are reported as follows: chemical shift, multiplicity ( $s=$ singlet, $\mathrm{d}=$ doublet, $\mathrm{t}=$ triplet, $\mathrm{q}=$ quartet, $\mathrm{m}=$ multiplet, $\mathrm{dd}=$ doublet of doublets, $\mathrm{td}=$ triplet of doublets), integration, and coupling constant $(J)$ in Hertz $(\mathrm{Hz})$. Analytical liquid chromatography coupled with mass spectrometry (LC-MS) was performed on a C4 Jupiter SuC4300A $150 \times 2.0 \mathrm{~mm}$ column using $\mathrm{H}_{2} \mathrm{O}$ with $0.1 \%$ formic acid (FA) and acetonitrile with $0.1 \% \mathrm{FA}$, in general with a gradient of $5 \%$ to $100 \%$ acetonitrile in $\mathrm{H}_{2} \mathrm{O}$ in $15 \mathrm{~min}$ (connected to a Thermo Fischer LCQ Fleet ion trap mass spectrometer). Preparative high pressure liquid chromatography (HP-LC) was performed on a Gemini S4 110A $150 \times 21.20 \mathrm{~mm}$ column using $\mathrm{H}_{2} \mathrm{O}$ with $0.1 \%$ F.A. and Acetonitrile with $0.1 \%$ FA. Silica column chromatography was performed manually using silica gel with particle size $60-200 \mu \mathrm{m}$ (60 ̊). Reaction progress was monitored by thin-layer chromatography using Merck TLC silica gel 60 F254 plates.

tert-Butyl (S)-2-Benzoylpyrrolidine-1-carboxylate (2.2). To an oven-dried $100 \mathrm{~mL}$ two-necked flask was added magnesium turnings $(1.18 \mathrm{~g}, 48.4 \mathrm{mmol})$ and anhydrous tetrahydrofuran (THF, $10 \mathrm{~mL}$ ) under argon pressure. A small amount of iodine was added followed by the slow addition of bromobenzene $(3.80 \mathrm{~g}, 24.2 \mathrm{mmol})$. The reaction was slowly heated using a heat gun to start the reaction and it was then stirred at room temperature for $30 \mathrm{~min}$. Subsequently, the reaction was cooled down to $0{ }^{\circ} \mathrm{C}$, at which time the Weinreb amide 2.1 (2.50 g, $9.7 \mathrm{mmol})$ in THF $(6 \mathrm{~mL})$ was added slowly. The resultant mixture was stirred at $0{ }^{\circ} \mathrm{C}$ for $3 \mathrm{~h}$, and then quenched with saturated $\mathrm{NH}_{4} \mathrm{Cl}$ $(15 \mathrm{~mL})$ and extracted with EtOAc $(3 \times 30 \mathrm{~mL})$. The combined organic layers were washed with brine, dried over $\mathrm{Na}_{2} \mathrm{SO}_{4}$, filtered, and concentrated in vacuo. The product was purified by column chromatography, eluting with heptane/EtOAc $72: 28 \mathrm{v} / \mathrm{v}$ to yield tert-butyl (S)-2-benzoylpyrrolidine-1-carboxylate (2.2) as a white powder (1.24 g, $4.50 \mathrm{mmol}, 47 \%)$. Silica gel TLC $R_{f}=0.23$ (heptane/EtOAc 72:28 v/v); LC-MS (ESI): calcd for $\mathrm{C}_{16} \mathrm{H}_{21} \mathrm{NO}_{3}[\mathrm{M}$ $+\mathrm{H}-\mathrm{BOC}]^{+}$: 176.10, observed 176.25, LC, $\mathrm{R}_{\mathrm{t}}=6.76 \mathrm{~min} ;{ }^{1} \mathrm{H}$ NMR $\left(400 \mathrm{MHz}, \mathrm{CDCl}_{3}\right): \delta(\mathrm{ppm}) 8.02-7.91(\mathrm{~m}, 2 \mathrm{H}), 7.62-7.52(\mathrm{~m}, 1 \mathrm{H})$, 7.51-7.41 (m, 2H), 5.37-5.16 (m, 1H), 3.73-3.42 (m, 2H), 2.40$2.24(\mathrm{~m}, 1 \mathrm{H}), 2.02-1.85(\mathrm{~m}, 3 \mathrm{H}), 1.47(\mathrm{~s}, 9 \mathrm{H}) ;{ }^{13} \mathrm{C} \mathrm{NMR}(100 \mathrm{MHz}$, $\left.\mathrm{CDCl}_{3}\right): \delta 198.92,154.45,135.29,133.19,128.70,128.69,128.52$, $128.51,79.78,61.36,46.81,29.82,28.21,28.20,28.19,24.18$.

(S)-Phenyl(pyrrolidin-2-yl)methanone (2.3). The $t$-Boc-protected amine 2.2 (1.14 g, $4.1 \mathrm{mmol})$ was dissolved in dichloromethane $(25$ $\mathrm{mL})$ and a solution of trifluoroacetic acid $(10 \mathrm{~mL})(70: 30 \mathrm{v} / \mathrm{v})$ was added. The reaction was stirred at room temperature for $2 \mathrm{~h}$. The solvent was evaporated, yielding $(S)$-phenyl(pyrrolidin-2-yl)methanone (2.3) (718 mg, $4.1 \mathrm{mmol}$, 99\%), which was directly used without purification. LC-MS (ESI): calcd for $\mathrm{C}_{11} \mathrm{H}_{13} \mathrm{NO}[\mathrm{M}+$ $\mathrm{H}]^{+}:$176.10, observed 176.25, LC, $\mathrm{R}_{\mathrm{t}}=2.38 \mathrm{~min} ;{ }^{1} \mathrm{H}$ NMR (400 $\left.\mathrm{MHz}, \mathrm{CDCl}_{3}\right): \delta(\mathrm{ppm}) 7.98(\mathrm{~d}, J=7.6 \mathrm{~Hz}, 2 \mathrm{H}), 7.72(\mathrm{t}, J=7.6 \mathrm{~Hz}$, $1 \mathrm{H}), 7.60-7.52(\mathrm{~m}, 2 \mathrm{H}), 5.56-5.47(\mathrm{~m}, 1 \mathrm{H}), 3.69-3.52(\mathrm{~m}, 2 \mathrm{H})$, $2.80-2.68(\mathrm{~m}, 1 \mathrm{H}), 2.30-2.18(\mathrm{~m}, 1 \mathrm{H}), 2.16-1.97(\mathrm{~m}, 2 \mathrm{H}) ;{ }^{13} \mathrm{C}$ NMR $\left(100 \mathrm{MHz}, \mathrm{CDCl}_{3}\right): \delta 193.67,135.79,131.26,129.33,129.32$, 129.21, 129.19, 63.18, 47.47, 30.22, 24.32.

Ethyl (S)-2-Benzoylpyrrolidine-1-carboxylate (2.4). (S)-Phenyl(pyrrolidin-2-yl)methanone (2.3) (500 mg, $2.58 \mathrm{mmol}$ ) was dissolved 
in methanol $(25 \mathrm{~mL}) . \mathrm{K}_{2} \mathrm{CO}_{3}(1.58 \mathrm{~g}, 11.4 \mathrm{mmol})$ was added followed by ethyl chloroformate $(340 \mathrm{mg}, 3.1 \mathrm{mmol})$ and the reaction mixture was stirred for $24 \mathrm{~h}$ at room temperature. The reaction mixture was quenched with $\mathrm{NH}_{4} \mathrm{Cl}(15 \mathrm{~mL})$ and extracted with EtOAc $(3 \times 30$ $\mathrm{mL}$ ). The combined organic layers were washed with brine, dried over $\mathrm{Na}_{2} \mathrm{SO}_{4}$, and filtered. Evaporation of solvent afforded ethyl (S)-2benzoylpyrrolidine-1-carboxylate (2.4) $(501 \mathrm{mg}, 2.0 \mathrm{mmol}, 71 \%)$ as a yellow oil. LC-MS (ESI): calcd for $\mathrm{C}_{14} \mathrm{H}_{17} \mathrm{NO}_{3}[\mathrm{M}+\mathrm{H}]^{+}: 248.12$, observed 248.08, LC, $\mathrm{R}_{\mathrm{t}}=5.89 \mathrm{~min} ;{ }^{1} \mathrm{H}$ NMR $\left(400 \mathrm{MHz}, \mathrm{CDCl}_{3}\right): \delta$ (ppm) 8.04-7.91 (m, 2H), 7.63-7.53 (m, 1H), 7.52-7.43 (m, 2H), 5.44-5.19 (m, 1H), 4.27-3.90 (m, 2H), 3.77-3.43 (m, 2H), 2.44$2.22(\mathrm{~m}, 1 \mathrm{H}), 2.02-1.86(\mathrm{~m}, 3 \mathrm{H}), 1.28(\mathrm{t}, J=6.8 \mathrm{~Hz}, 3 \mathrm{H}) ;{ }^{13} \mathrm{C}$ NMR $\left(100 \mathrm{MHz}, \mathrm{CDCl}_{3}\right): \delta 198.31,155.15,135.06,133.30,128.73,128.73$, 128.53, 128.52, 61.39, 61.15, 47.00, 30.90, 24.25, 14.77.

General Procedure for the Synthesis of Pyrrolooxazolones 2.5ag. To an oven-dried, either 50 or $100 \mathrm{~mL}$ two-necked flask were added the magnesium turnings and anhydrous THF under an argon atmosphere. A catalytic (spatula end) amount of iodine was added, followed by slow addition of the substituted bromobenzene neat via Hamilton gastight syringe. The reaction was gently heated to initiate the reaction, and stirred at room temperature for $30 \mathrm{~min}$. Subsequently, the reaction was cooled down to $0{ }^{\circ} \mathrm{C}$ and a $1 \mathrm{~mL}$ solution of 2.4 in THF introduced through slow dropwise addition. The resulting mixture was stirred at $0{ }^{\circ} \mathrm{C}$ for $2 \mathrm{~h}$, and then warmed to $70{ }^{\circ} \mathrm{C}$. With the exception of analogue $2.5 \mathrm{a}$, which was heated for $3 \mathrm{~h}$ and worked up directly, in the general case, the reaction was monitored by measuring LC-MS on small aliquots of the reaction, and heated for $24 \mathrm{~h}$. For the workup, the reaction mixture was cooled to room temperature, quenched through addition of sat. aq. $\mathrm{NH}_{4} \mathrm{Cl}(5$ $\mathrm{mL})$, and extracted with EtOAc $(3 \times 30 \mathrm{~mL})$. The combined organic layers were washed with brine, dried over $\mathrm{Na}_{2} \mathrm{SO}_{4}$, filtered and then concentrated in vacuo. Except with the synthesis of analogues 2.5a, $2.5 \mathrm{~b}$, and $2.5 \mathrm{~g}$, which proceeded directly to the purification step, the crude material was dissolved in methanol $(3 \mathrm{~mL})$ and treated with either $100 \mathrm{mg} \mathrm{NaOH}$ (2.5c and 2.5d) or $500 \mathrm{mg} \mathrm{KOH} \mathrm{(2.5e} \mathrm{and}$ 2.5f) to promote further ring-closure to the pyrrolooxazolone. In these latter cases, the reaction was stirred at room temperature for $24 \mathrm{~h}$ and worked up as described previously. The isolated crude was purified by either silica gel column chromatography $(2.5 \mathrm{a}, 2.5 \mathrm{~b}, 2.5 \mathrm{c}, 2.5 \mathrm{~d}$, and $2.5 \mathrm{~g}$ ) or reversed-phase flash chromatography on a Biotage Isolera system (2.5e and 2.5f) to yield the pure pyrrolooxazolone after evaporation of elution solvents under reduced pressure.

Pyrrolooxazolone 2.5a. The synthesis was performed in accordance with the general method using magnesium turnings (39 $\mathrm{mg}, 1.6 \mathrm{mmol}$ ) suspended in $5 \mathrm{~mL}$ of anhydrous THF, 2bromotoluene $(138 \mathrm{mg}, 0.81 \mathrm{mmol})$, and $2.4(95 \mathrm{mg}, 384 \mu \mathrm{mol})$. The product was purified by silica gel column chromatography, eluting with heptane/EtOAc 70:10 v/v to yield pyrrolooxazolone 2.5a as a yellow oil (129 mg, $330 \mathrm{mmol}, 86 \%)$. Silica gel TLC $R_{f}=0.30$ (heptane/EtOAc 70:30 v/v); LC-MS (ESI): calcd for $\mathrm{C}_{19} \mathrm{H}_{19} \mathrm{NO}_{2}$ [M $+\mathrm{H}]^{+}:$294.14, observed 294.17, LC, $\mathrm{R}_{\mathrm{t}}=7.08 \mathrm{~min} ;{ }^{1} \mathrm{H}$ NMR $(400$ $\left.\mathrm{MHz}, \mathrm{CDCl}_{3}\right): \delta(\mathrm{ppm}) 7.55-7.50(\mathrm{~m}, 1 \mathrm{H}), 7.34-7.26(\mathrm{~m}, 5 \mathrm{H})$, $7.22-7.13(\mathrm{~m}, 3 \mathrm{H}), 4.81(\mathrm{dd}, J=9.0,6.2 \mathrm{~Hz}, 1 \mathrm{H}), 3.69-3.59(\mathrm{~m}$, $1 \mathrm{H}), 3.28-3.19(\mathrm{~m}, 1 \mathrm{H}), 2.11(\mathrm{~s}, 3 \mathrm{H}), 1.95-1.76(\mathrm{~m}, 2 \mathrm{H}), 1.63-1.49$ $(\mathrm{m}, 1 \mathrm{H}), 1.28-1.16(\mathrm{~m}, 1 \mathrm{H}) ;{ }^{13} \mathrm{C}$ NMR $\left(100 \mathrm{MHz}, \mathrm{CDCl}_{3}\right): \delta$ $159.64,140.15,139.03,138.69,133.00,128.65,128.21,128.20,127.65$, $125.87,125.87,125.52,125.24,87.98,67.66,45.35,27.96,26.00$, 21.56.

Pyrrolooxazolone 2.5b. The synthesis was performed in accordance with the general method using magnesium turnings (39 $\mathrm{mg}, 1.6 \mathrm{mmol}$ ) suspended in $5 \mathrm{~mL}$ of anhydrous THF, 3bromotoluene (138 mg, $0.81 \mathrm{mmol}$ ), and $2.4(95 \mathrm{mg}, 384 \mu \mathrm{mol})$. The product was purified by silica gel column chromatography, eluting with heptane/EtOAc 70:30 v/v to yield pyrrolooxazolone $2.5 \mathbf{b}$ as a yellow oil (46 mg, $157 \mu \mathrm{mol}, 41 \%$ ). Silica gel TLC $R_{f}=0.29$ (heptane/ EtOAc 70:30 v/v); LC-MS (ESI): calcd for $\mathrm{C}_{19} \mathrm{H}_{19} \mathrm{NO}_{2}[\mathrm{M}+\mathrm{H}]^{+}$: 294.14, observed 294.08, LC, $\mathrm{R}_{\mathrm{t}}=7.11 \mathrm{~min} ;{ }^{1} \mathrm{H} \mathrm{NMR}(400 \mathrm{MHz}$, $\left.\mathrm{CDCl}_{3}\right): \delta(\mathrm{ppm}) 7.42-7.28(\mathrm{~m}, 7 \mathrm{H}), 7.25-7.21(\mathrm{~m}, 1 \mathrm{H}), 7.12(\mathrm{~d}, J=$ $7.5 \mathrm{~Hz}, 1 \mathrm{H}), 4.54(\mathrm{dd}, J=10.5,5.5 \mathrm{~Hz}, 1 \mathrm{H}), 3.78-3.68(\mathrm{~m}, 1 \mathrm{H})$, $3.29-3.20(\mathrm{~m}, 1 \mathrm{H}), 2.34(\mathrm{~s}, 3 \mathrm{H}), 2.04-1.62(\mathrm{~m}, 3 \mathrm{H}), 1.18-1.06(\mathrm{~m}$,
$1 \mathrm{H}) ;{ }^{13} \mathrm{C} \mathrm{NMR}\left(100 \mathrm{MHz}, \mathrm{CDCl}_{3}\right): \delta 160.48,143.24,140.43,138.34$ $129.07,128.39,128.28,128.28,127.63,126.58,125.45,125.44,122.90$, 85.91, 69.24, 46.02, 28.98, 24.93, 21.59.

Pyrrolooxazolone 2.5c. The synthesis was performed in accordance with the general method using magnesium turnings $(49 \mathrm{mg}, 2.0$ $\mathrm{mmol}$ ) suspended in $4 \mathrm{~mL}$ of anhydrous THF, 1-bromo-2-(2methoxyethoxy)-benzene (280 $\mathrm{mg}, 0.81 \mathrm{mmol})$, and $2.4(80 \mathrm{mg}$, $324 \mu \mathrm{mol})$. The product was purified by silica gel column chromatography, eluting with heptane/EtOAc $60: 40 \mathrm{v} / \mathrm{v}$ to yield pyrrolooxazolone $2.5 \mathrm{c}$ as a yellow oil $(65 \mathrm{mg}, 184 \mu \mathrm{mol}, 57 \%)$. Silica gel TLC $R_{f}=0.34$ (heptane/EtOAc 60:40 v/v); LC-MS (ESI): calcd for $\mathrm{C}_{21} \mathrm{H}_{23} \mathrm{NO}_{4}[\mathrm{M}+\mathrm{H}]^{+}:$354.16, observed 354.00, LC, $\mathrm{R}_{\mathrm{t}}=6.83$ min; ${ }^{1} \mathrm{H}$ NMR $\left(400 \mathrm{MHz}, \mathrm{CDCl}_{3}\right): \delta(\mathrm{ppm}) 7.71(\mathrm{dd}, J=7.9,1.7 \mathrm{~Hz}$, $1 \mathrm{H}), 7.52-7.46(\mathrm{~m}, 2 \mathrm{H}), 7.34-7.27(\mathrm{~m}, 3 \mathrm{H}), 7.25-7.18(\mathrm{~m}, 1 \mathrm{H})$, $7.03-6.90(\mathrm{~m}, 2 \mathrm{H}), 4.85(\mathrm{dd}, J=9.0,6.2 \mathrm{~Hz}, 1 \mathrm{H}), 4.23-4.16(\mathrm{~m}$, $2 \mathrm{H}), 3.81-3.69(\mathrm{~m}, 2 \mathrm{H}), 3.69-3.61(\mathrm{~m}, 1 \mathrm{H}), 3.41(\mathrm{~s}, 3 \mathrm{H}), 3.19-3.09$ (m, $1 \mathrm{H}), 2.03-1.93(\mathrm{~m}, 1 \mathrm{H}), 1.90-1.80(\mathrm{~m}, 2 \mathrm{H}), 1.39-1.25(\mathrm{~m}, 1 \mathrm{H})$; ${ }^{13} \mathrm{C}$ NMR $\left(100 \mathrm{MHz}, \mathrm{CDCl}_{3}\right): \delta 159.53,154.38,140.42,131.80$, $129.39,127.83,127.83,127.58,127.18,126.39,126.39,121.38,112.03$, 86.80, 70.74, 68.46, 66.96, 58.78, 45.24, 28.76, 25.81.

Pyrrolooxazolone 2.5d. The synthesis was performed in accordance with the general method using magnesium turnings (49 $\mathrm{mg}, 2.0 \mathrm{mmol}$ ) suspended in $4 \mathrm{~mL}$ of anhydrous THF, 1-bromo-3-(2methoxyethoxy)-benzene $(280 \mathrm{mg}, 0.81 \mathrm{mmol})$, and $2.4(100 \mathrm{mg}, 404$ $\mu \mathrm{mol})$. The product was purified by silica gel column chromatography, eluting with heptane/EtOAc 60:40 v/v to yield pyrrolooxazolone $2.5 \mathrm{~d}$ as a yellow oil (114 mg, $323 \mu \mathrm{mol}, 80 \%)$. Silica gel TLC $R_{f}=0.24$ (heptane/EtOAc 60:40 v/v); LC-MS (ESI): calcd for $\mathrm{C}_{21} \mathrm{H}_{23} \mathrm{NO}_{4}[\mathrm{M}$ $+\mathrm{H}]^{+}:$354.16, observed 353.92, LC, $\mathrm{R}_{\mathrm{t}}=6.68 \mathrm{~min} ;{ }^{1} \mathrm{H}$ NMR $(400$ $\left.\mathrm{MHz}, \mathrm{CDCl}_{3}\right): \delta(\mathrm{ppm}) 7.40-7.27(\mathrm{~m}, 6 \mathrm{H}), 7.15-7.08(\mathrm{~m}, 2 \mathrm{H})$, 6.88-6.83 (m, 1H), 4.52 (dd, $J=10.4,5.5 \mathrm{~Hz}, 1 \mathrm{H}), 4.11-4.07(\mathrm{~m}$, $2 \mathrm{H}), 3.77-3.66(\mathrm{~m}, 3 \mathrm{H}), 3.43(\mathrm{~s}, 3 \mathrm{H}), 3.28-3.19(\mathrm{~m}, 1 \mathrm{H}), 2.02-1.78$ $(\mathrm{m}, 2 \mathrm{H}), 1.75-1.65(\mathrm{~m}, 1 \mathrm{H}), 1.18-1.04(\mathrm{~m}, 1 \mathrm{H}) ;{ }^{13} \mathrm{C}$ NMR $(100$ $\left.\mathrm{MHz}, \mathrm{CDCl}_{3}\right): \delta 160.33,158.89,144.89,140.18,129.54,128.29$, $128.28,127.71,125.43,125.43,118.40,113.83,113.14,85.80,70.97$, 69.22, 67.26, 59.21, 45.99, 28.96, 24.95.

Pyrrolooxazolone 2.5e. The synthesis was performed in accordance with the general method using magnesium turnings (49 $\mathrm{mg}$, $2.0 \mathrm{mmol}$ ) suspended in $4 \mathrm{~mL}$ anhydrous THF, 2-bromoanisole $(151 \mathrm{mg}, 0.81 \mathrm{mmol})$, and $2.4(100 \mathrm{mg}, 404 \mu \mathrm{mol})$. The product was purified by reversed-phase flash chromatography on a Biotage Isolera system, eluting with a gradient of $5-100 \% \mathrm{ACN}$ in $\mathrm{H}_{2} \mathrm{O}$ to yield pyrrolooxazolone $2.5 \mathrm{e}$ as a yellow oil (40 $\mathrm{mg}, 129 \mathrm{mmol}, 32 \%)$. LCMS (ESI): calcd for $\mathrm{C}_{19} \mathrm{H}_{19} \mathrm{NO}_{3}[\mathrm{M}+\mathrm{H}]^{+}: 310.14$, observed 310.08 , LC, $\mathrm{R}_{\mathrm{t}}=6.49 \mathrm{~min} ;{ }^{1} \mathrm{H}$ NMR $\left(400 \mathrm{MHz}, \mathrm{CDCl}_{3}\right): \delta(\mathrm{ppm}) 7.67(\mathrm{dd}, J$ $=7.8,1.7 \mathrm{~Hz}, 1 \mathrm{H}), 7.41-7.27(\mathrm{~m}, 5 \mathrm{H}), 7.25-7.20(\mathrm{~m}, 1 \mathrm{H}), 7.06-6.91$ (m, $2 \mathrm{H}), 4.72(\mathrm{dd}, J=8.7,6.2 \mathrm{~Hz}, 1 \mathrm{H}), 3.86(\mathrm{~s}, 3 \mathrm{H}), 3.72-3.60(\mathrm{~m}$, $1 \mathrm{H}), 3.21-3.09(\mathrm{~m}, 1 \mathrm{H}), 1.98-1.90(\mathrm{~m}, 1 \mathrm{H}), 1.89-1.80(\mathrm{~m}, 2 \mathrm{H})$, $1.45-1.32(\mathrm{~m}, 1 \mathrm{H}) ;{ }^{13} \mathrm{C}$ NMR $\left(100 \mathrm{MHz}, \mathrm{CDCl}_{3}\right): \delta 159.32,155.28$, $140.27,131.63$, 129.49, 127.95, 127.94, 127.68, 127.10, 126.29, 126.28, $121.34,111.63,87.13,68.72,55.21,45.19,28.68,25.92$.

Pyrrolooxazolone 2.5f. The synthesis was performed in accordance with the general method using magnesium turnings (49 mg, 2.0 $\mathrm{mmol}$ ) suspended in $4 \mathrm{~mL}$ of anhydrous THF, 3-bromoanisole (151 $\mathrm{mg}, 0.81 \mathrm{mmol})$, and $2.4(100 \mathrm{mg}, 404 \mu \mathrm{mol})$. The product was purified by reversed-phase flash chromatography on a Biotage Isolera system, eluting with a gradient of $5-100 \% \mathrm{ACN}$ in $\mathrm{H}_{2} \mathrm{O}$ to yield pyrrolooxazolone $\mathbf{2 . 5 f}$ as a yellow oil ( $31 \mathrm{mg}, 100 \mu \mathrm{mol}, 25 \%)$. LC-MS (ESI): calcd for $\mathrm{C}_{19} \mathrm{H}_{19} \mathrm{NO}_{3}[\mathrm{M}+\mathrm{H}]^{+}: 310.14$, observed 310.17, LC, $\mathrm{R}_{\mathrm{t}}=6.43 \mathrm{~min} ;{ }^{1} \mathrm{H}$ NMR $\left(400 \mathrm{MHz}, \mathrm{CDCl}_{3}\right): \delta(\mathrm{ppm}) 7.42-7.26(\mathrm{~m}$, $6 \mathrm{H}), 7.12(\mathrm{~d}, J=8.0 \mathrm{~Hz}, 1 \mathrm{H}), 7.06(\mathrm{t}, J=2.2 \mathrm{~Hz}, 1 \mathrm{H}), 6.84(\mathrm{dd}, J=$ 8.0, $2.4 \mathrm{~Hz}, 1 \mathrm{H}), 4.53(\mathrm{dd}, J=10.5,5.5 \mathrm{~Hz}, 1 \mathrm{H}), 3.78(\mathrm{~s}, 3 \mathrm{H}), 3.75-$ $3.68(\mathrm{~m}, 1 \mathrm{H}), 3.32-3.18(\mathrm{~m}, 1 \mathrm{H}), 2.04-1.80(\mathrm{~m}, 2 \mathrm{H}), 1.77-1.67(\mathrm{~m}$, $1 \mathrm{H}), 1.20-1.05(\mathrm{~m}, 1 \mathrm{H}) ;{ }^{13} \mathrm{C}$ NMR $\left(100 \mathrm{MHz}, \mathrm{CDCl}_{3}\right): \delta 160.36$, 159.72 , 144.93, 140.21, 129.56, 128.30, 128.30, 127.72, 125.42, 125.42, 118.07, 113.44, 112.23, 85.83, 69.29, 55.32, 45.99, 28.98, 24.95.

Pyrrolooxazolone 2.5g. The synthesis was performed in accordance with the general method using magnesium turnings (49 $\mathrm{mg}, 2.0 \mathrm{mmol}$ ) suspended in $4 \mathrm{~mL}$ of anhydrous THF, 3-bromophenyl isopropyl ether $(217 \mathrm{mg}, 1.0 \mathrm{mmol})$, and $2.4(100 \mathrm{mg}, 404 \mu \mathrm{mol})$. 
The product was purified by silica gel column chromatography, eluting with $\mathrm{CH}_{2} \mathrm{Cl}_{2} /$ heptane 80:20 v/v to yield pyrrolooxazolone $2.5 \mathrm{~g}$ as a yellow oil $(117 \mathrm{mg}, 347 \mu \mathrm{mol}, 86 \%)$. Silica gel TLC $R_{f}=0.29$ (DCM/ heptane 80:20 v/v); LC-MS (ESI): calcd for $\mathrm{C}_{21} \mathrm{H}_{23} \mathrm{NO}_{3}[\mathrm{M}+\mathrm{H}]^{+}$: 338.17, observed 338.08, LC, $\mathrm{R}_{\mathrm{t}}=7.12 \mathrm{~min}$; ${ }^{1} \mathrm{H}$ NMR $(400 \mathrm{MHz}$, $\left.\mathrm{CDCl}_{3}\right): \delta(\mathrm{ppm}) 7.42-7.26(\mathrm{~m}, 5 \mathrm{H}), 7.26-7.22(\mathrm{~m}, 1 \mathrm{H}), 7.10-7.03$ $(\mathrm{m}, 2 \mathrm{H}), 6.82(\mathrm{dd}, J=8.0,2.0 \mathrm{~Hz}, 1 \mathrm{H}), 4.57-4.47(\mathrm{~m}, 2 \mathrm{H}), 3.78-$ $3.67(\mathrm{~m}, 1 \mathrm{H}), 3.29-3.19(\mathrm{~m}, 1 \mathrm{H}), 2.00-1.80(\mathrm{~m}, 2 \mathrm{H}), 1.76-1.66(\mathrm{~m}$, $1 \mathrm{H}), 1.30(\mathrm{dd}, J=7.8,6.1 \mathrm{~Hz}, 6 \mathrm{H}), 1.18-1.04(\mathrm{~m}, 1 \mathrm{H}) ;{ }^{13} \mathrm{C}$ NMR $\left(101 \mathrm{MHz}, \mathrm{CDCl}_{3}\right): \delta 160.39,158.00,144.94,140.27,129.52,128.29$, $128.27,127.67,125.45,125.44,117.91,114.95,114.19,85.83,69.89$, 69.27, 45.99, 28.99, 24.95, 22.00, 21.98 .

General Procedure for the Synthesis of Asymmetrically Substituted Benzhydryl Pyrrolidine Analogues 2.6a-g. A $25 \mathrm{~mL}$, glass round-bottomed flask was loaded with the pyrrolooxazolone precursor, dissolved in either pure ethyl acetate or a methanol/ethyl acetate solvent mixture, and treated with the catalyst, $\mathrm{Pd} / \mathrm{C}(10 \%)$. The flask was flushed with hydrogen gas for $15 \mathrm{~min}, 50 \mu \mathrm{L}$ of triethylamine was added to the reaction mixture, and the reaction stirred at room temperature under a hydrogen atmosphere for $24 \mathrm{~h}$. The catalyst was filtered off by passing the reaction mixture through Celite, eluting with EtOAc. The solvent was removed under reduced pressure to obtain the benzhydryl pyrrolidine analogue. For analogues 2.6a, 2.6b, and $2.6 \mathrm{~g}$, the material was used without further purification. Analogues 2.6c, 2.6d, 2.6e, and 2.6f were further purified by reversed-phase preparative HPLC to isolated separable diastereomers.

Benzhydryl Pyrrolidine Analogue 2.6a. The synthesis was performed in accordance with the general method using 2.5a (50 $\mathrm{mg}, 170 \mu \mathrm{mol})$ and $\mathrm{Pd} / \mathrm{C}(10 \%)(25 \mathrm{mg})$ in methanol $(1.5 \mathrm{~mL})$ and ethyl acetate $(0.5 \mathrm{~mL})$ to form $2.6 \mathrm{a}(33 \mathrm{mg}, 131 \mu \mathrm{mol}, 77 \%)$, which was directly used without purification. LC-MS (ESI): calcd for $\mathrm{C}_{18} \mathrm{H}_{21} \mathrm{~N}[\mathrm{M}+\mathrm{H}]^{+}:$:252.17, observed 252.17, LC, $\mathrm{R}_{\mathrm{t}}=4.94 \mathrm{~min} ;{ }^{1} \mathrm{H}$ NMR $\left(400 \mathrm{MHz}, \mathrm{CDCl}_{3}\right): \delta(\mathrm{ppm}) 7.42-7.28(\mathrm{~m}, 7 \mathrm{H}), 7.25-7.21$ $(\mathrm{m}, 1 \mathrm{H}), 7.12(\mathrm{~d}, J=7.5 \mathrm{~Hz}, 1 \mathrm{H}), 4.54(\mathrm{dd}, J=10.5,5.5 \mathrm{~Hz}, 1 \mathrm{H})$, $3.78-3.68(\mathrm{~m}, 1 \mathrm{H}), 3.29-3.20(\mathrm{~m}, 1 \mathrm{H}), 2.34(\mathrm{~s}, 3 \mathrm{H}), 2.04-1.62(\mathrm{~m}$, $3 \mathrm{H}), 1.18-1.06(\mathrm{~m}, 1 \mathrm{H}) ;{ }^{13} \mathrm{C} \mathrm{NMR}\left(100 \mathrm{MHz}, \mathrm{CDCl}_{3}\right): \delta 160.48$, $143.24,140.43,138.34,129.07,128.39,128.28,128.28,127.63,126.58$, $125.45,125.44,122.90,85.91,69.24,46.02,28.98,24.93,21.59$.

Benzhydryl Pyrrolidine Analogue 2.6b. The synthesis was performed in accordance with the general method using $\mathbf{2 . 5 b}$ (45 $\mathrm{mg}, 153 \mu \mathrm{mol})$ and $\mathrm{Pd} / \mathrm{C}(10 \%)(25 \mathrm{mg})$ in methanol $(1.5 \mathrm{~mL})$ and ethyl acetate $(0.5 \mathrm{~mL})$ to form $2.6 \mathrm{~b}(22 \mathrm{mg}, 88 \mu \mathrm{mol}, 59 \%)$, which was directly used without purification. LC-MS (ESI): calcd for $\mathrm{C}_{18} \mathrm{H}_{21} \mathrm{~N}[\mathrm{M}+\mathrm{H}]^{+}:$:252.17, observed 252.25, LC, $\mathrm{R}_{\mathrm{t}}=4.52$; ${ }^{1} \mathrm{H}$ NMR $\left(400 \mathrm{MHz}, \mathrm{CDCl}_{3}\right): \delta(\mathrm{ppm}) 7.36(\mathrm{~d}, J=7.2 \mathrm{~Hz}, 1 \mathrm{H}), 7.30-7.24(\mathrm{~m}$, $2 \mathrm{H}), 7.19-7.06(\mathrm{~m}, 5 \mathrm{H}), 6.97(\mathrm{~d}, J=7.1 \mathrm{~Hz}, 1 \mathrm{H}), 3.95-3.83(\mathrm{~m}$, $1 \mathrm{H}), 3.77(\mathrm{~d}, J=10.2 \mathrm{~Hz}, 1 \mathrm{H}), 3.04-2.80(\mathrm{~m}, 2 \mathrm{H}), 2.30(\mathrm{~s}, 3 \mathrm{H})$, $1.86-1.70(\mathrm{~m}, 3 \mathrm{H}), 1.50-1.38(\mathrm{~m}, 1 \mathrm{H}) ;{ }^{13} \mathrm{C}$ NMR $(100 \mathrm{MHz}$, $\left.\mathrm{CDCl}_{3}\right): \delta 143.40,143.24,138.03,128.86,128.66,128.66,128.36$, $128.07,128.07,127.19,126.47,124.95,62.18,57.88,45.92,30.57$, 24.57, 21.51.

Benzhydryl Pyrrolidine Analogue 2.6c. The synthesis was performed in accordance with the general method using 2.5c (56 $\mathrm{mg}, 158 \mu \mathrm{mol})$ and $\mathrm{Pd} / \mathrm{C}(10 \%)(35 \mathrm{mg})$ in methanol $(1.9 \mathrm{~mL})$ and ethyl acetate $(0.6 \mathrm{~mL})$ to form $\mathbf{2 . 6 c}$, which was purified further by preparative HPLC (gradient of $15-40 \% \mathrm{ACN}$ in $12 \mathrm{~min}$.), to obtain the two different diastereomers $2.6 \mathrm{c}-\mathrm{I}(2 \mathrm{mg}, 7 \mu \mathrm{mol}, 4 \%)$ and $2.6 \mathrm{c}-\mathrm{II}$ (22 mg, $71 \mu \mathrm{mol}, 44 \%$ ) as pure compounds. 2.6c-I: LC-MS (ESI): calcd for $\mathrm{C}_{20} \mathrm{H}_{25} \mathrm{NO}_{2}[\mathrm{M}+\mathrm{H}]^{+}: 312.19$, observed 312.25, LC, $\mathrm{R}_{\mathrm{t}}=$ $4.44 \mathrm{~min} ;{ }^{1} \mathrm{H}$ NMR $\left(400 \mathrm{MHz}, \mathrm{CDCl}_{3}\right): \delta(\mathrm{ppm}) 7.41(\mathrm{~d}, J=7.6 \mathrm{~Hz}$, $2 \mathrm{H}), 7.30(\mathrm{t}, J=7.6 \mathrm{~Hz}, 2 \mathrm{H}), 7.23-7.14(\mathrm{~m}, 2 \mathrm{H}), 7.04(\mathrm{~d}, J=7.6 \mathrm{~Hz}$, $1 \mathrm{H}), 6.93-6.79(\mathrm{~m}, 2 \mathrm{H}), 4.84(\mathrm{~d}, J=8.3 \mathrm{~Hz}, 1 \mathrm{H}), 4.58-4.49(\mathrm{~m}$, $1 \mathrm{H}), 4.17-4.06(\mathrm{~m}, 2 \mathrm{H}), 3.89-3.72(\mathrm{~m}, 2 \mathrm{H}), 3.53(\mathrm{~s}, 3 \mathrm{H}), 3.05-2.95$ (m, $1 \mathrm{H}), 2.88-2.73(\mathrm{~m}, 1 \mathrm{H}), 2.10-1.99(\mathrm{~m}, 1 \mathrm{H}), 1.94-1.81(\mathrm{~m}, 1 \mathrm{H})$, $1.79-1.65(\mathrm{~m}, 2 \mathrm{H}) ;{ }^{13} \mathrm{C}$ NMR (100 MHz, $\left.\mathrm{CDCl}_{3}\right): \delta 155.47,140.05$, $130.00,129.99,129.29,129.27,128.74,128.70,128.41,127.01,121.42$, $111.73,70.57,67.52,61.60,59.44,47.41,45.34,29.50,24.08 .2 .6 \mathrm{c}-\mathrm{II}$ : LC-MS (ESI): calcd for $\mathrm{C}_{20} \mathrm{H}_{25} \mathrm{NO}_{2}[\mathrm{M}+\mathrm{H}]^{+}: 312.19$, observed 312.33, LC, $\mathrm{R}_{\mathrm{t}}=4.55 \mathrm{~min} ;{ }^{1} \mathrm{H}$ NMR $\left(400 \mathrm{MHz}, \mathrm{CDCl}_{3}\right): \delta(\mathrm{ppm})$ $7.37-7.27(\mathrm{~m}, 5 \mathrm{H}), 7.23-7.16(\mathrm{~m}, 2 \mathrm{H}), 6.95(\mathrm{t}, J=7.6 \mathrm{~Hz}, 1 \mathrm{H}), 6.84$ $(\mathrm{d}, J=8.4 \mathrm{~Hz}, 1 \mathrm{H}), 4.56-4.44(\mathrm{~m}, 2 \mathrm{H}), 4.14(\mathrm{t}, J=4.7 \mathrm{~Hz}, 2 \mathrm{H})$, 3.81-3.61 (m, $2 \mathrm{H}), 3.44(\mathrm{~s}, 3 \mathrm{H}), 3.15(\mathrm{~m}, 1 \mathrm{H}), 2.98(\mathrm{~m}, 1 \mathrm{H}), 2.02$ $(\mathrm{m}, 1 \mathrm{H}), 1.96-1.87(\mathrm{~m}, 2 \mathrm{H}), 1.67(\mathrm{~m}, 1 \mathrm{H}) ;{ }^{13} \mathrm{C}$ NMR $(100 \mathrm{MHz}$, $\left.\mathrm{CDCl}_{3}\right): \delta 167.99,155.41,140.72,129.94,128.65,128.60,128.59$, $128.28,128.28,126.92,121.76,111.95,70.64,66.81,61.60,59.06$, 48.83, 45.35, 30.88, 24.06.

Benzhydryl Pyrrolidine Analogue 2.6d. The synthesis was performed in accordance with the general method using $2.5 \mathrm{~d}$ (110 $\mathrm{mg}, 311 \mu \mathrm{mol})$ and $\mathrm{Pd} / \mathrm{C}(10 \%)(50 \mathrm{mg})$ in methanol $(2.6 \mathrm{~mL})$ and ethyl acetate $(0.9 \mathrm{~mL})$ to form $\mathbf{2 . 6 \mathrm { d }}$, which was purified further by preparative HPLC (gradient of $15-40 \% \mathrm{ACN}$ in $12 \mathrm{~min}$.), to obtain two different diastereomers $2.6 \mathrm{~d}-\mathrm{I}$ ( $53 \mathrm{mg}, 170 \mu \mathrm{mol}, 55 \%)$ and $\mathbf{2 . 6 \mathrm { d } -}$ II $(16 \mathrm{mg}, 51 \mu \mathrm{mol}, 16 \%)$ as pure compounds. 2.6d-I: LC-MS (ESI): calcd for $\mathrm{C}_{20} \mathrm{H}_{25} \mathrm{NO}_{2}[\mathrm{M}+\mathrm{H}]^{+}$: 312.19, observed 312.25, LC, $\mathrm{R}_{\mathrm{t}}=$ $4.14 \mathrm{~min} ;{ }^{1} \mathrm{H}$ NMR $\left(400 \mathrm{MHz}, \mathrm{CDCl}_{3}\right): \delta(\mathrm{ppm}) 7.40(\mathrm{~d}, J=7.7 \mathrm{~Hz}$, $2 \mathrm{H}), 7.33-7.26(\mathrm{~m}, 2 \mathrm{H}), 7.22-7.11(\mathrm{~m}, 2 \mathrm{H}), 6.87-6.79(\mathrm{~m}, 2 \mathrm{H})$, $6.74(\mathrm{~d}, J=8.4 \mathrm{~Hz}, 1 \mathrm{H}), 4.17-4.10(\mathrm{~m}, 2 \mathrm{H}), 4.05(\mathrm{t}, \mathrm{J}=4.4 \mathrm{~Hz}, 2 \mathrm{H})$, $3.72(\mathrm{t}, J=5.2,2 \mathrm{H}), 3.44(\mathrm{~s}, 3 \mathrm{H}), 2.75-2.66(\mathrm{~m}, 2 \mathrm{H}), 1.92-1.83(\mathrm{~m}$, $2 \mathrm{H}), 1.81-1.71(\mathrm{~m}, 1 \mathrm{H}), 1.68-1.57(\mathrm{~m}, 1 \mathrm{H}) ;{ }^{13} \mathrm{C}$ NMR $(100 \mathrm{MHz}$, $\left.\mathrm{CDCl}_{3}\right): \delta 159.01,143.13,140.43,129.85,128.90,128.90,128.11$, $128.10,127.15,120.16,114.34,112.67,70.98,67.15,62.11,59.25$, 54.75, 44.89, 30.76, 23.82. 2.6d-II: LC-MS (ESI): calcd for $\mathrm{C}_{20} \mathrm{H}_{25} \mathrm{NO}_{2}[\mathrm{M}+\mathrm{H}]^{+}: 312.19$, observed 312.25, LC, $\mathrm{R}_{\mathrm{t}}=4.40$ min; ${ }^{1} \mathrm{H}$ NMR $\left(400 \mathrm{MHz}, \mathrm{CDCl}_{3}\right): \delta(\mathrm{ppm}) 7.26-7.16(\mathrm{~m}, 6 \mathrm{H}), 7.11-$ $7.00(\mathrm{~m}, 2 \mathrm{H}), 6.76(\mathrm{~d}, J=8.1 \mathrm{~Hz}, 1 \mathrm{H}), 4.24-4.10(\mathrm{~m}, 4 \mathrm{H}), 3.72(\mathrm{t}, J=$ $4.4 \mathrm{~Hz}, 2 \mathrm{H}), 3.42(\mathrm{~s}, 3 \mathrm{H}), 2.91(\mathrm{t}, J=7.1 \mathrm{~Hz}, 2 \mathrm{H}), 2.00-1.77(\mathrm{~m}$, $3 \mathrm{H}), 1.73-1.60(\mathrm{~m}, 1 \mathrm{H}) ;{ }^{13} \mathrm{C}$ NMR $\left(100 \mathrm{MHz} \mathrm{CDCl}_{3}\right): \delta 159.04$, $130.18,128.91,128.91,127.60,127.60,127.22,120.56,114.26,113.91$, 71.08, 67.20, 62.81, 59.19, 54.80, 45.37, 30.67, 23.71.

Benzhydryl Pyrrolidine Analogue 2.6e. The synthesis was performed in accordance with the general method using 2.5e (40 $\mathrm{mg}, 129 \mu \mathrm{mol})$ and $\mathrm{Pd} / \mathrm{C}(10 \%)(30 \mathrm{mg})$ in methanol $(1.0 \mathrm{~mL})$ and ethyl acetate $(0.6 \mathrm{~mL})$ to form $2.6 \mathrm{e}$, which was purified further by preparative HPLC (19\% ACN in $15 \mathrm{~min}$.), to obtain the two different diastereomers 2.6e-I (6 mg, $22 \mu \mathrm{mol}, 17 \%)$ and 2.6e-II $(10 \mathrm{mg}, 37$ $\mu \mathrm{mol}, 28 \%$ ) as pure compounds. 2.6e-I: LC-MS (ESI): calcd for $\mathrm{C}_{18} \mathrm{H}_{21} \mathrm{NO}[\mathrm{M}+\mathrm{H}]^{+}:$268.16, observed 268.25, LC, $\mathrm{R}_{\mathrm{t}}=3.67 \mathrm{~min} ;{ }^{1} \mathrm{H}$ $\operatorname{NMR}\left(400 \mathrm{MHz}, \mathrm{CDCl}_{3}\right): \delta(\mathrm{ppm}) 7.38-7.32(\mathrm{~m}, 2 \mathrm{H}), 7.24-7.07$ $(\mathrm{m}, 5 \mathrm{H}), 6.92-6.77(\mathrm{~m}, 2 \mathrm{H}), 4.61(\mathrm{~d}, J=11.3 \mathrm{~Hz}, 1 \mathrm{H}), 4.53-4.38$ $(\mathrm{m}, 1 \mathrm{H}), 3.81(\mathrm{~s}, 3 \mathrm{H}), 2.88-2.73(\mathrm{~m}, 2 \mathrm{H}), 1.99-1.81(\mathrm{~m}, 3 \mathrm{H}), 1.75-$ $1.62(\mathrm{~m}, 1 \mathrm{H}) ;{ }^{13} \mathrm{C}$ NMR $\left(100 \mathrm{MHz}, \mathrm{CDCl}_{3}\right): \delta 156.50,139.97$, $129.44,128.66,128.65,128.41,128.30,128.24,128.23,127.00,120.99$, $111.15,62.11,55.45,47.48,45.49,29.95,23.70$. 2.6e-II: LC-MS (ESI): calcd for $\mathrm{C}_{18} \mathrm{H}_{21} \mathrm{NO}[\mathrm{M}+\mathrm{H}]^{+}: 268.16$, observed 268.25, $\mathrm{LC}, \mathrm{R}_{\mathrm{t}}=3.70$ $\min ;{ }^{1} \mathrm{H}$ NMR (400 MHz, $\left.\mathrm{CDCl}_{3}\right): \delta(\mathrm{ppm}) 7.35(\mathrm{dd}, J=7.6,1.6 \mathrm{~Hz}$, $1 \mathrm{H}), 7.26-7.20(\mathrm{~m}, 4 \mathrm{H}), 7.20-7.11(\mathrm{~m}, 2 \mathrm{H}), 6.88(\mathrm{td}, J=7.5,1.1 \mathrm{~Hz}$, $1 \mathrm{H}), 6.77(\mathrm{dd}, J=8.3,1.1 \mathrm{~Hz}, 1 \mathrm{H}), 4.47(\mathrm{~d}, J=11.7 \mathrm{~Hz}, 1 \mathrm{H}), 4.45-$ $4.35(\mathrm{~m}, 1 \mathrm{H}), 3.74(\mathrm{~s}, 3 \mathrm{H}), 2.88-2.68(\mathrm{~m}, 2 \mathrm{H}), 2.01-1.83(\mathrm{~m}, 4 \mathrm{H})$; ${ }^{13} \mathrm{C}$ NMR $\left(100 \mathrm{MHz}, \mathrm{CDCl}_{3}\right) \delta 157.06,140.61,128.61,128.61$, $128.44,128.13,128.12,128.11,127.95,127.01,120.83,110.87,61.72$, 55.28, 48.28, 45.37, 30.83, 23.80.

Benzhydryl Pyrrolidine Analogue 2.6f. The synthesis was performed in accordance with the general method using 2.5f (30 $\mathrm{mg}, 97 \mu \mathrm{mol})$ and $\mathrm{Pd} / \mathrm{C}(10 \%)(25 \mathrm{mg})$ in methanol $(1.0 \mathrm{~mL})$ and ethyl acetate $(1.0 \mathrm{~mL})$ to form $\mathbf{2 . 6 f}$, which was purified further by preparative HPLC ( $20 \% \mathrm{ACN}$ in $15 \mathrm{~min}$.), to obtain the two different diastereomers 2.6f-I (7 mg, $26 \mu \mathrm{mol}, 26 \%)$ and 2.6f-II ( $2 \mathrm{mg}, 7 \mu \mathrm{mol}$, $7 \%$ ) as pure compounds. 2.6f-I: LC-MS (ESI): calcd for $\mathrm{C}_{18} \mathrm{H}_{21} \mathrm{NO}$ $[\mathrm{M}+\mathrm{H}]^{+}: 268.16$, observed $268.25, \mathrm{LC}, \mathrm{R}_{\mathrm{t}}=3.55 \mathrm{~min} .{ }^{1} \mathrm{H}$ NMR (400 $\left.\mathrm{MHz}, \mathrm{CDCl}_{3}\right): \delta(\mathrm{ppm}) 7.39(\mathrm{~d}, J=7.6 \mathrm{~Hz}, 2 \mathrm{H}), 7.31-7.27(\mathrm{~m}, 2 \mathrm{H})$, $7.21-7.13(\mathrm{~m}, 2 \mathrm{H}), 6.84(\mathrm{~d}, J=8.0 \mathrm{~Hz}, 1 \mathrm{H}), 6.79(\mathrm{t}, J=2.0 \mathrm{~Hz}, 1 \mathrm{H})$, $6.72(\mathrm{dd}, J=8.0,2.0 \mathrm{~Hz}, 1 \mathrm{H}), 4.17-4.04(\mathrm{~m}, 2 \mathrm{H}), 3.75(\mathrm{~s}, 3 \mathrm{H}), 2.78-$ $2.69(\mathrm{~m}, 2 \mathrm{H}), 1.93-1.82(\mathrm{~m}, 2 \mathrm{H}), 1.81-1.73(\mathrm{~m}, 1 \mathrm{H}), 1.67-1.56(\mathrm{~m}$ $1 \mathrm{H}) ;{ }^{13} \mathrm{C}$ NMR $\left(100 \mathrm{MHz}, \mathrm{CDCl}_{3}\right): \delta 159.79,143.41,140.91,129.83$, $128.87,128.86,128.09,128.08,127.09,119.95,113.75,112.07,62.09$, 55.18, 55.17, 44.96, 30.69, 23.92. 2.6f-II: LC-MS (ESI): calcd for $\mathrm{C}_{18} \mathrm{H}_{21} \mathrm{NO}[\mathrm{M}+\mathrm{H}]^{+}: 268.16$, observed 268.25, LC, $\mathrm{R}_{\mathrm{t}}=3.63 \mathrm{~min} ;{ }^{1} \mathrm{H}$ NMR $\left(400 \mathrm{MHz}, \mathrm{CDCl}_{3}\right): \delta(\mathrm{ppm}) 7.40-7.27(\mathrm{~m}, 2 \mathrm{H}), 7.26-7.16$ $(\mathrm{m}, 5 \mathrm{H}), 7.06(\mathrm{~d}, J=7.7 \mathrm{~Hz}, 1 \mathrm{H}), 7.02(\mathrm{t}, J=2.1 \mathrm{~Hz}, 1 \mathrm{H}), 6.72(\mathrm{dd}, J$ 
$=8.3,2.4 \mathrm{~Hz}, 1 \mathrm{H}), 4.24-4.10(\mathrm{~m}, 2 \mathrm{H}), 3.82(\mathrm{~s}, 3 \mathrm{H}), 2.86(\mathrm{t}, J=7.2$ $\mathrm{Hz}, 2 \mathrm{H}), 1.98-1.74(\mathrm{~m}, 3 \mathrm{H}), 1.72-1.60(\mathrm{~m}, 1 \mathrm{H}) ;{ }^{13} \mathrm{C}$ NMR $(100$ $\left.\mathrm{MHz}, \mathrm{CDCl}_{3}\right): \delta 159.86,141.86,141.27,130.08,128.96,128.94$, $127.61,127.60,127.22,120.37,113.62,113.36,99.99,62.66,55.33$, 54.88, 45.36, 30.82, 23.74.

Benzhydryl Pyrrolidine Analogue 2.6g. The synthesis was performed in accordance with the general method using $2.5 \mathrm{~g}$ (95 $\mathrm{mg}, 282 \mu \mathrm{mol})$ and $\mathrm{Pd} / \mathrm{C}(10 \%)(50 \mathrm{mg})$ in ethyl acetate $(3.0 \mathrm{~mL})$ to form $2.6 \mathrm{~g}$ (67 mg, $227 \mu \mathrm{mol}, 81 \%)$, which was used directly without further purification. LC-MS (ESI): calcd for $\mathrm{C}_{20} \mathrm{H}_{25} \mathrm{NO}[\mathrm{M}+\mathrm{H}]^{+}$: 296.19, observed 296.25, LC, $\mathrm{R}_{\mathrm{t}}=4.16 \mathrm{~min}$; ${ }^{1} \mathrm{H}$ NMR $(400 \mathrm{MHz}$, $\left.\mathrm{CDCl}_{3}\right): \delta(\mathrm{ppm}) 7.40-7.26(\mathrm{~m}, 4 \mathrm{H}), 7.22-7.12(\mathrm{~m}, 2 \mathrm{H}), 6.90-6.80$ $(\mathrm{m}, 2 \mathrm{H}), 6.72-6.65(\mathrm{~m}, 1 \mathrm{H}), 4.56-4.44(\mathrm{~m}, 1 \mathrm{H}), 3.90-3.78(\mathrm{~m}, 1 \mathrm{H})$, $3.72(\mathrm{dd}, J=10.3,2.4 \mathrm{~Hz}, 1 \mathrm{H}), 3.07-2.82(\mathrm{~m}, 2 \mathrm{H}), 1.87-1.70(\mathrm{~m}$, $3 \mathrm{H}), 1.49-1.39(\mathrm{~m}, 1 \mathrm{H}), 1.31(\mathrm{dd}, J=6.1,1.6 \mathrm{~Hz}, 6 \mathrm{H}) ;{ }^{13} \mathrm{C} \mathrm{NMR}$ $\left(100 \mathrm{MHz}, \mathrm{CDCl}_{3}\right): \delta 157.85,145.01,143.43,129.35,128.65,128.65$, $128.04,128.03,126.47,120.28,116.19,112.98,69.66,62.15,58.22$, 45.98, 30.48, 24.61, 22.08, 22.04 .

General Procedure for the Synthesis of Partially Protected Tau Peptides 3.1a-f. The partially protected Tau peptides $3.1 \mathrm{a}-\mathrm{f}$ were prepared in accordance with a previous published synthesis of 3.1a. ${ }^{12}$ In each case, the peptides were synthesized on a $50 \mu \mathrm{mol}$ scale by automated peptide synthesis (Intavis MultiPep RSi) using a Fmoc SPPS strategy performed on a 2-chlorotrityl resin (Iris Biotech $\mathrm{GmbH}$ and AGTC Bioproducts) preloaded with the corresponding Cterminal amino acid. The Fmoc-protected amino acid building blocks (4.2 eq., $0.5 \mathrm{M}$, Novabiochem) were dissolved in $\mathrm{N}$-methyl-2pyrrolidone (NMP) and coupled sequentially to the resin using $\mathrm{N}, \mathrm{N}$-diisopropylethylamine (DIPEA, 8 equiv, prepared as $1.6 \mathrm{M}$ stock solution in NMP, Biosolve) and (2-(1H-benzotriazol-1-yl)-1,1,3,3tetramethyluronium hexafluorophosphate (HBTU, 4 equiv, $0.4 \mathrm{M}$ stock solution in NMP, Biosolve). Each amino acid coupling was repeated once to ensure complete conversion. Fmoc-deprotection was performed using 20\% piperidine in NMP (twice per cycle). The peptide $\mathrm{N}$-terminus was $\mathrm{N}$-acetylated prior to resin cleavage using $\mathrm{Ac}_{2} \mathrm{O} /$ pyridine/NMP (1:1:3). Resin cleavage of the partially protected peptide was performed using 30\% hexafluoroisopropanol (HFIP, Sigma-Aldrich) in $\mathrm{CH}_{2} \mathrm{Cl}_{2}(1 \mathrm{~mL}$ per $100 \mathrm{mg}$ resin, $1 \times 20 \mathrm{~min}, 1 \times 10$ $\mathrm{min}$.) and the organic solvents removed to dryness by rotary evaporation. The isolated material was then redissolved in acetonitrile/water/0.1\% trifluoroacetic acid (TFA) and lyophilized to obtain a white powder. The yields of the crude partially protected peptides were typically $>90 \%$ yield. The partially protected peptides were characterized by The partially protected peptides were characterized by Analytical Liquid Chromatography coupled with Mass Spectrometry (LC-MS), via one of the following methods:

Method A: using a C4 Jupiter SuC4300A $150 \times 2.0 \mathrm{~mm}$ column using $\mathrm{H}_{2} \mathrm{O}$ with $0.1 \%$ formic acid (FA) and acetonitrile with $0.1 \%$ FA with a gradient of $5 \%$ to $100 \%$ acetonitrile in $\mathrm{H}_{2} \mathrm{O}$ in $15 \mathrm{~min}$ (connected to a Thermo Fischer LCQ Fleet ion trap mass spectrometer.

Method B: using a C18 Atlantis T3 $5 \mu \mathrm{m} 150 \times 1 \mathrm{~mm}$ column using $\mathrm{H}_{2} \mathrm{O}$ with $0.1 \%$ trifluoroacetic acid (TFA) and acetonitrile with $0.1 \%$ TFA with a gradient of $5 \%$ to $100 \%$ acetonitrile in $\mathrm{H}_{2} \mathrm{O}$ in 15 min (connected to a Thermo Finnigan LCQ Deca XP MAX mass spectrometer) (see the Supporting Information for LC-MS spectra).

General Procedure for the Synthesis of Modified Tau Peptides $3.2 b-f$ and $4.2 a-g$. The modified Tau inhibitors $3.2 b-f$ and $4.2 \mathrm{a}-\mathrm{g}$ were prepared in accordance with a previously published synthesis of 3.2a. ${ }^{12}$ A $25 \mathrm{~mL}$ round-bottomed flask fitted with a magnetic stirring bar was charged with the partially protected Tau peptide (3.1b-f, 1.1 equiv). The peptide was dissolved in $\mathrm{N}, \mathrm{N}$-dimethylformamide (DMF, $0.06 \mathrm{M})$ and treated with 6-chloro-benzotriazole-1-yl-oxy-trispyrrolidino-phosphonium hexafluorosphate (PyClock) (Novabiochem, 1.5 equiv). The reaction mixture was stirred for $15 \mathrm{~min}$, which was followed by the sequential addition of $\mathrm{N}, \mathrm{N}$-diisoproylethylamine (DIPEA, 5 equiv) and 1 equiv of either (S)-2-(diphenylmethyl)pyrrolidine, for the synthesis of modified tau peptides $3.2 \mathrm{a}-\mathbf{f}$, or benzhydryl pyrrolidine analogues $\mathbf{2 . 6 a}-\mathbf{g}$, for the synthesis of modified tau peptides $4.2 \mathrm{a}-\mathrm{g}$. The reaction was left to stir, conversion monitored by LC-MS, and then worked up after $24 \mathrm{~h}$ by evaporating the organic solvent under reduced pressure to obtain the crude material. Deprotection of the side-chain protecting groups was performed by stirring the crude material for $3 \mathrm{~h}$ in a 95/2.5/2.5 (v/ v) mixture of TFA $/ \mathrm{H}_{2} \mathrm{O} /$ triisopropylsilane (TIS) $(0.016 \mathrm{M})$. The peptide was then precipitated into $40 \mathrm{~mL}$ ice-cold diethyl ether $\left(\mathrm{Et}_{2} \mathrm{O}\right)$, stored at $-30{ }^{\circ} \mathrm{C}$ for $10 \mathrm{~min}$, centrifuged at $2500 \mathrm{rpm}$ for 10 min and the supernatant decanted. Fresh ice-cold $\mathrm{Et}_{2} \mathrm{O}(40 \mathrm{~mL})$ was added to pellet, and the subsequent step repeated. The crude pellet was dissolved in $\mathrm{H}_{2} \mathrm{O} / \mathrm{ACN}+0.1 \%$ TFA and then purified by reversed-phase HPLC using a C18 column (Atlantis T3 prep OBD, 19 $\times 150 \mathrm{~mm}$ ) using the optimized gradient conditions described below beside each modified peptide. After purification the aqueous organic solvent mixture was removed by lyophilization to obtain the modified Tau inhibitors 3.2 a-f and 4.2a-g, typically as white amorphous powders. Afterward, the modified tau peptides were characterized by analytical liquid chromatography coupled with mass spectrometry (LC-MS) using a C18 Atlantis T3 $5 \mu \mathrm{m} 150 \times 1 \mathrm{~mm}$ column using $\mathrm{H}_{2} \mathrm{O}$ with $0.1 \%$ TFA and acetonitrile with $0.1 \%$ TFA with a gradient of $5 \%$ to $100 \%$ acetonitrile in $\mathrm{H}_{2} \mathrm{O}$ in 15 min (connected to a Thermo Finnigan LCQDeca XP MAX mass spectrometer) (see the Supporting Information for LC-MS spectra). In the case of Tau inhibitors $\mathbf{4 . 2 c - f}$, two diastereomers (I and II) were separated, which were studied separately in the subsequent biochemical and X-ray crystallography studies.

Modified Tau Peptide 3.2a. The synthesis was performed in accordance with the general method using (S)-2-(diphenylmethyl)pyrrolidine $(9 \mathrm{mg}, 37 \mu \mathrm{mol})$ and purification performed by preparative reversed-phase HPLC using a linear gradient of $40-45 \% \mathrm{MeCN}$ to form $3.2 \mathrm{a}(3 \mathrm{mg}, 3 \mu \mathrm{mol}, 8 \%)$. LC-MS (ESI): calcd for $\mathrm{C}_{52} \mathrm{H}_{78} \mathrm{~N}_{11} \mathrm{O}_{14} \mathrm{P}_{1}[\mathrm{M}+\mathrm{H}]^{+}:$1112.55, observed 1112.6, LC, $\mathrm{R}_{\mathrm{t}}=$ $7.62 \mathrm{~min}$.

Modified Tau Peptide 3.2b. The synthesis was performed in accordance with the general method using (S)-2-(diphenylmethyl)pyrrolidine $(10 \mathrm{mg}, 42 \mu \mathrm{mol})$ and purification performed by preparative reversed-phase HPLC using a linear gradient of $40-45 \%$ $\mathrm{MeCN}$ to form $3.2 b$ ( $11 \mathrm{mg}, 10 \mu \mathrm{mol}, 24 \%)$. LC-MS (ESI): calcd for $\mathrm{C}_{50} \mathrm{H}_{74} \mathrm{~N}_{11} \mathrm{O}_{13} \mathrm{P}_{1}[\mathrm{M}+\mathrm{H}]^{+}: 1068.52$, observed 1068.5, LC, $\mathrm{R}_{\mathrm{t}}=7.87$ $\min$.

Modified Tau Peptide 3.2c. The synthesis was performed in accordance with the general method using $(S)$-2-(diphenylmethyl)pyrrolidine $(10 \mathrm{mg}, 42 \mu \mathrm{mol})$ and purification performed by preparative reversed-phase HPLC using a linear gradient of $40-45 \%$ $\mathrm{MeCN}$ to form 3.2c (16 mg, $15 \mu \mathrm{mol}, 36 \%)$. LC-MS (ESI): calcd for $\mathrm{C}_{51} \mathrm{H}_{76} \mathrm{~N}_{11} \mathrm{O}_{13} \mathrm{P}_{1}[\mathrm{M}+\mathrm{H}]^{+}: 1082.54$, observed 1082.6, LC, $\mathrm{R}_{\mathrm{t}}=8.00$ min.

Modified Tau Peptide 3.2d. The synthesis was performed in accordance with the general method using (S)-2-(diphenylmethyl)pyrrolidine $(10 \mathrm{mg}, 42 \mu \mathrm{mol})$ and purification performed by preparative reversed-phase HPLC using a linear gradient of $40-45 \%$ $\mathrm{MeCN}$ to form 3.2d (13 mg, $12 \mu \mathrm{mol}, 29 \%)$. LC-MS (ESI): calcd for $\mathrm{C}_{51} \mathrm{H}_{76} \mathrm{~N}_{11} \mathrm{O}_{13} \mathrm{P}_{1}[\mathrm{M}+\mathrm{H}]^{+}:$1082.54, observed 1082.6, LC, $\mathrm{R}_{\mathrm{t}}=8.02$ min.

Modified Tau Peptide 3.2e. The synthesis was performed in accordance with the general method using $(S)$-2-(diphenylmethyl)pyrrolidine $(8 \mathrm{mg}, 34 \mu \mathrm{mol}$ ) and purification performed by preparative reversed-phase HPLC using a linear gradient of $40-45 \% \mathrm{MeCN}$ to form 3.2e (10 mg, $9 \mu \mathrm{mol}, 26 \%)$. LC-MS (ESI): calcd for $\mathrm{C}_{53} \mathrm{H}_{80} \mathrm{~N}_{11} \mathrm{O}_{13} \mathrm{P}_{1}[\mathrm{M}+\mathrm{H}]^{+}: 1110.57$, observed 1110.7, LC, $\mathrm{R}_{\mathrm{t}}=$ 8.82 min.

Modified Tau Peptide 3.2f. The synthesis was performed in accordance with the general method using $(S)$-2-(diphenylmethyl)pyrrolidine $(8 \mathrm{mg}, 34 \mu \mathrm{mol})$, and purification performed by preparative reversed-phase HPLC using a linear gradient of $40-45 \%$ $\mathrm{MeCN}$ to form $3.2 \mathrm{f}$ ( $4 \mathrm{mg}, 4 \mu \mathrm{mol}, 12 \%)$. LC-MS (ESI): calcd for $\mathrm{C}_{53} \mathrm{H}_{80} \mathrm{~N}_{11} \mathrm{O}_{13} \mathrm{P}_{1}[\mathrm{M}+\mathrm{H}]^{+}: 1110.57$, observed 1110.7, LC, $\mathrm{R}_{\mathrm{t}}=8.83$ $\min$.

Modified Tau Peptide 4.2a. The synthesis was performed in accordance with the general method using benzhydryl pyrrolidine analogue $2.6 \mathrm{a}(7 \mathrm{mg}, 28 \mu \mathrm{mol}$ ), and purification performed by 
preparative reversed-phase HPLC using a linear gradient of 38-43\% $\mathrm{MeCN}$ to form 4.2a as an inseparable mixture of diastereomers $(9 \mathrm{mg}$, $8 \mu \mathrm{mol}, 29 \%)$. LC-MS (ESI): calcd for $\mathrm{C}_{51} \mathrm{H}_{76} \mathrm{~N}_{11} \mathrm{O}_{13} \mathrm{P}_{1}[\mathrm{M}+\mathrm{H}]^{+}$: 1082.54, observed 1082.6, LC, $\mathrm{R}_{\mathrm{t}}=8.38 \mathrm{~min}$.

Modified Tau Peptide 4.2b. The synthesis was performed in accordance with the general method using benzhydryl pyrrolidine analogue $2.6 \mathbf{b}(8 \mathrm{mg}, 32 \mu \mathrm{mol})$, and purification performed by preparative reversed-phase HPLC using a linear gradient of $37-42 \%$ $\mathrm{MeCN}$ to form $4.2 \mathrm{~b}$ as an inseparable mixture of diastereomers $(5 \mathrm{mg}$, $5 \mu \mathrm{mol}, 16 \%$ ). LC-MS (ESI): calcd for $\mathrm{C}_{51} \mathrm{H}_{76} \mathrm{~N}_{11} \mathrm{O}_{13} \mathrm{P}_{1}[\mathrm{M}+\mathrm{H}]^{+}$: 1082.54, observed 1082.6, LC, $\mathrm{R}_{\mathrm{t}}=8.42 \mathrm{~min}$.

Isomeric Modified Tau Peptide 4.2c-I. The synthesis was performed in accordance with the general method using isomeric benzhydryl pyrrolidine analogue 2.6c-I ( $2 \mathrm{mg}, 6 \mu \mathrm{mol})$, and purification performed by preparative reversed-phase HPLC using a linear gradient of $37-42 \% \mathrm{MeCN}$ to form $4.2 \mathrm{c}-\mathrm{I}(1 \mathrm{mg}, 1 \mu \mathrm{mol}, 17 \%)$. LC-MS (ESI): calcd for $\mathrm{C}_{53} \mathrm{H}_{80} \mathrm{~N}_{11} \mathrm{O}_{15} \mathrm{P}_{1}[\mathrm{M}+\mathrm{H}]^{+}$: 1142.56 , observed 1142.7, LC, $\mathrm{R}_{\mathrm{t}}=8.05 \mathrm{~min}$.

Isomeric Modified Tau Peptides 4.2c-II. The synthesis was performed in accordance with the general method using isomeric benzhydryl pyrrolidine analogue $2.6 \mathrm{c}-\mathrm{II}(9 \mathrm{mg}, 29 \mu \mathrm{mol}$ ), and purification performed by preparative reversed-phase HPLC using a linear gradient of $37-42 \% \mathrm{MeCN}$ to form $4.2 \mathrm{c}-\mathrm{II}(7 \mathrm{mg}, 6 \mu \mathrm{mol}$, 21\%). LC-MS (ESI): calcd for $\mathrm{C}_{53} \mathrm{H}_{80} \mathrm{~N}_{11} \mathrm{O}_{15} \mathrm{P}_{1}[\mathrm{M}+\mathrm{H}]^{+}$: 1142.56, observed 1142.6, LC, $\mathrm{R}_{\mathrm{t}}=8.35 \mathrm{~min}$.

Isomeric Modified Tau Peptide 4.2d-I. The synthesis was performed in accordance with the general method using isomeric benzhydryl pyrrolidine analogue $2.6 \mathrm{~d}-\mathrm{I}(12 \mathrm{mg}, 39 \mu \mathrm{mol})$, and purification performed by preparative reversed-phase HPLC using a linear gradient of $37-42 \% \mathrm{MeCN}$ to form $4.2 \mathrm{~d}-\mathrm{I}(1 \mathrm{mg}, 1 \mu \mathrm{mol}, 3 \%)$. LC-MS (ESI): calcd for $\mathrm{C}_{53} \mathrm{H}_{80} \mathrm{~N}_{11} \mathrm{O}_{15} \mathrm{P}_{1}[\mathrm{M}+\mathrm{H}]^{+}: 1142.56$, observed $1142.8, \mathrm{LC}, \mathrm{R}_{\mathrm{t}}=8.07 \mathrm{~min}$.

Isomeric Modified Tau Peptides 4.2d-II. The synthesis was performed in accordance with the general method using isomeric benzhydryl pyrrolidine analogue $2.6 \mathrm{~d}-\mathrm{II}$ ( $4 \mathrm{mg}, 13 \mu \mathrm{mol})$, and purification performed by preparative reversed-phase HPLC using a linear gradient of $35-40 \% \mathrm{MeCN}$ to form $4.2 \mathrm{~d}-\mathrm{II}(4 \mathrm{mg}, 4 \mu \mathrm{mol}$, $31 \%)$. LC-MS (ESI): calcd for $\mathrm{C}_{53} \mathrm{H}_{80} \mathrm{~N}_{11} \mathrm{O}_{15} \mathrm{P}_{1}[\mathrm{M}+\mathrm{H}]^{+}: 1142.56$, observed 1142.7, LC, $\mathrm{R}_{\mathrm{t}}=8.23 \mathrm{~min}$.

Isomeric Modified Tau Peptide 4.2e-I. The synthesis was performed in accordance with the general method using isomeric benzhydryl pyrrolidine analogue 2.6e-I ( $4 \mathrm{mg}, 15 \mu \mathrm{mol}$ ), and purification performed by preparative reversed-phase HPLC using a linear gradient of $37-42 \% \mathrm{MeCN}$ to form $4.2 \mathrm{e}-\mathrm{I}$ ( $4 \mathrm{mg}, 4 \mu \mathrm{mol}, 27 \%)$. LC-MS (ESI): calcd for $\mathrm{C}_{51} \mathrm{H}_{76} \mathrm{~N}_{11} \mathrm{O}_{14} \mathrm{P}_{1}[\mathrm{M}+\mathrm{H}]^{+}: 1098.53$, observed 1098.9, LC, $\mathrm{R}_{\mathrm{t}}=7.60 \mathrm{~min}$.

Isomeric Modified Tau Peptides 4.2e-II. The synthesis was performed in accordance with the general method using isomeric benzhydryl pyrrolidine analogue $2.6 \mathrm{e}-\mathrm{II}(7 \mathrm{mg}, 26 \mu \mathrm{mol})$, and purification performed by preparative reversed-phase HPLC using a linear gradient of $35-40 \% \mathrm{MeCN}$ to form $4.2 \mathrm{e}-\mathrm{II}(6 \mathrm{mg}, 5 \mu \mathrm{mol}$, 19\%). LC-MS (ESI): calcd for $\mathrm{C}_{51} \mathrm{H}_{76} \mathrm{~N}_{11} \mathrm{O}_{14} \mathrm{P}_{1}[\mathrm{M}+\mathrm{H}]^{+}:$: 1098.53, observed 1098.7, LC, $\mathrm{R}_{\mathrm{t}}=8.32 \mathrm{~min}$.

Isomeric Modified Tau Peptide 4.2f-I. The synthesis was performed in accordance with the general method using isomeric benzhydryl pyrrolidine analogue $2.6 \mathrm{f}-\mathrm{I}(6 \mathrm{mg}, 22 \mu \mathrm{mol})$, and purification performed by preparative reversed-phase HPLC using a linear gradient of $37-42 \% \mathrm{MeCN}$ to form $4.2 \mathrm{f}-\mathrm{I}(8 \mathrm{mg}, 7 \mathrm{mmol}$, $32 \%)$. LC-MS (ESI): calcd for $\mathrm{C}_{51} \mathrm{H}_{76} \mathrm{~N}_{11} \mathrm{O}_{14} \mathrm{P}_{1}[\mathrm{M}+\mathrm{H}]^{+}$: 1098.53, observed 1098.7, LC, $\mathrm{R}_{\mathrm{t}}=8.38 \mathrm{~min}$.

Isomeric Modified Tau Peptides 4.2f-II. The synthesis was performed in accordance with the general method using isomeric benzhydryl pyrrolidine analogue 2.6f-II ( $2 \mathrm{mg}, 8 \mu \mathrm{mol})$, and purification performed by preparative reversed-phase HPLC using a linear gradient of $35-40 \% \mathrm{MeCN}$ to form $4.2 \mathrm{f}-\mathrm{II}(2 \mathrm{mg}, 2 \mu \mathrm{mol}$, 25\%). LC-MS (ESI): calcd for $\mathrm{C}_{51} \mathrm{H}_{76} \mathrm{~N}_{11} \mathrm{O}_{14} \mathrm{P}_{1}[\mathrm{M}+\mathrm{H}]^{+}$: 1098.53, observed 1098.7, LC, $\mathrm{R}_{\mathrm{t}}=8.28 \mathrm{~min}$.

Modified Tau Peptide 4.2g. The synthesis was performed in accordance with the general method using benzhydryl pyrrolidine analogue $2.6 \mathrm{~g}(11 \mathrm{mg}, 37 \mu \mathrm{mol})$, and purification performed by preparative reversed-phase HPLC using a linear gradient of $40-45 \%$ $\mathrm{MeCN}$ to form $4.2 \mathrm{~g}$ as an inseparable mixture of diastereomers (1 mg, $1 \mu \mathrm{mol}, 3 \%$ ). LC-MS (ESI): calcd for $\mathrm{C}_{53} \mathrm{H}_{80} \mathrm{~N}_{11} \mathrm{O}_{14} \mathrm{P}_{1}[\mathrm{M}+\mathrm{H}]^{+}$: 1126.56, observed 1126.7, LC, $\mathrm{R}_{\mathrm{t}}=8.68 \mathrm{~min}$.

Biochemical Evaluation of Modified Tau Peptides 3.2a-f and $4.2 \mathrm{a}-\mathrm{g}$. Fluorescence Polarization Assays. FP assays were performed using $100 \mathrm{nM}$ FAM-labeled tethered Tau peptide (5,6FAM)-RTP(ps)LPTG(GGS) ${ }_{3}$ GSKCG(pS)LGNIHHK in buffer containing $10 \mathrm{mM}$ HEPES ( $\mathrm{pH} 7.4$ ), $10 \mathrm{mM} \mathrm{NaCl}, 0.1 \%$ (v/v) Tween20, and $0.1 \%(\mathrm{w} / \mathrm{v})$ bis(trimethylsilyl)acetamide (BSA). First, a dilution series of His-14-3-3 $\zeta$ to the labeled peptide was made in order to obtain a $K_{\mathrm{d}}$ value and select an appropriate concentration for the subsequent inhibition experiments. For the determination of $\mathrm{IC}_{50}$ values, dilution series of the inhibitor peptides were made to a solution

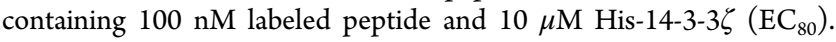
The assays were performed in Corning black, round-bottom, lowvolume, 384 microwell plates (ref 4514). The polarization was measured by use of a filter-based microplate reader (Tecan Infinite F500) using a fluorescein filter set $\left(\lambda_{\mathrm{ex}}: 485 \mathrm{~nm} / 20 \mathrm{~nm}, \lambda_{\mathrm{em}}: 535 \mathrm{~nm} /\right.$ $25 \mathrm{~nm}$ ) (10 reads per well). All experiments were performed in triplicate. To obtain $K_{\mathrm{d}}$ and $\mathrm{IC}_{50}$ values, the resulting curve was fitted by use of GraphPad Prism 6.0 for Windows (GraphPad Software Inc., La Jolla, CA).

Isothermal Titration Calorimetry. ITC experiments were performed on a Malvern $\mathrm{ITC}_{200}$ isothermal titration calorimeter (Microcal Inc.). The peptide and protein were separately dissolved in ITC-buffer containing $25 \mathrm{mM}$ HEPES ( $\mathrm{pH} 7.5$ ), $100 \mathrm{mM} \mathrm{NaCl}, 10 \mathrm{mM} \mathrm{MgCl}_{2}$ and $0.5 \mathrm{mM}$ TCEP (Tris(2-carboxyethyl)phosphine). In the sample

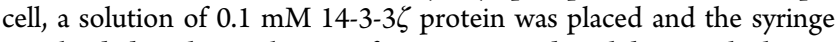
was loaded with a solution of $1 \mathrm{mM}$ peptide inhibitor, which was titrated stepwise into the cell with $2 \mu \mathrm{L}$ aliquots (with a delay of $180 \mathrm{~s}$ between each titration). For each measurement, a series of 19 injections was performed using the following settings: reference power, $5 \mu \mathrm{Cal} / \mathrm{s}$; initial delay, $60 \mathrm{~s}$; stirring speed, $750 \mathrm{rpm}$; temperature, 37 ${ }^{\circ} \mathrm{C}$. All measurements were performed in duplicate. The data was analyzed using Origin 7.0 software. A nonlinear regression analysis was performed, using a single-site binding model with varying stoichiometry $(N)$, association constant $\left(K_{\mathrm{a}}=1 / K_{\mathrm{d}}\right)$, and molar binding enthalpy $(\Delta H)$ to determine the thermodynamic parameters.

X-ray Crystallography Studies. Sitting Drop Crystallization of 14-3-3 $\sigma$-Peptide Complexes. The 14-3-3 $\sigma$ protein used for crystallization was truncated C-terminally after the Thr-231 residue to enhance crystallization, called $14-3-3 \sigma \Delta \mathrm{C}$. Crystallization was attempted for all Tau inhibitors $3.2 \mathrm{a}-\mathrm{f}$ and $4.2 \mathrm{a}-\mathrm{g}$ with 14-3-

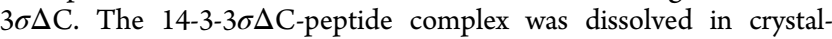
lization buffer ( $20 \mathrm{mM}$ HEPES (pH 7.5), $2 \mathrm{mM} \mathrm{MgCl}, 2 \mathrm{mM} \mathrm{BME}$ ) at a 1:1.5 and 1:5 molar ratio with a resulting protein concentration of $12.5 \mathrm{mg} / \mathrm{mL}$ and this incubated overnight at $4{ }^{\circ} \mathrm{C}$. A sitting drop crystal screen was set up on a 96-wells plate (Corning pZero 3550). First, $75 \mu \mathrm{L}$ of the optimized $14-3-3 \sigma \Delta \mathrm{C}$ screening conditions $(5 \%$ glycerol, $0.19 \mathrm{M} \mathrm{CaCl}_{2}$, varying concentration of PEG400 (24\%-29\% (v/v)), 0.095 M HEPES at varying $\mathrm{pH}$ of 7.1, 7.3, 7.5 and 7.7) were pipetted into the reservoirs. Then, by use of a pipetting robot (Mosquito), $500 \mathrm{~nL}$ drops were made by pipetting $250 \mathrm{~nL}$ of the screening conditions into $250 \mathrm{~nL}$ of protein-peptide complex. The plate was covered with an airtight foil, and incubated at $4{ }^{\circ} \mathrm{C}$. Crystals were harvested after 1-12 weeks and were flash-cooled in liquid nitrogen before measuring.

Data Collection and Processing. Diffraction data for 3.2a-d were collected at the Petra(III) synchrotron in Hamburg, and data for $\mathbf{4 . 2 b}$, 4.2c-I, 4.2e-I, 4.2f-I, and 4.2f-II were collected on a Rigaku Compact HomeLab beamline (home source). The data was processed using iMosflm ${ }^{46}$ in the ccp4i package or XDS and the structures were phased by molecular replacement (using PDB: 4Y3B) in Phenix Phaser. ${ }^{47}$ Refinement and model building were done with Phenix.refine ${ }^{48}$ and $\operatorname{Coot}^{49}$ software packages. Figures were made by PyMol (DeLano Scientific LLC, version 0.99rc6).

NMR Spectroscopy Studies on Full-Length PKA-Phosphorylated Tau Protein. ${ }^{15} \mathrm{~N}$ Labeled Tau Protein Expression and Purification. E. coli BL21 cells were transformed with the pET15b 
vector carrying the longest Tau isoform (2N4R, 441 amino acid residues). A $20 \mathrm{~mL}$ preculture in Luria-Bertani (LB) medium containing $100 \mu \mathrm{g} / \mathrm{mL}$ ampicillin was grown overnight at $37^{\circ} \mathrm{C}$ and was used to inoculate a $1 \mathrm{~L}$ culture in $\mathrm{M} 9$ minimal medium supplemented with $4 \mathrm{~g} / \mathrm{L}$ Glucose, $1 \mathrm{~g} / \mathrm{L}{ }^{15} \mathrm{NH}_{4} \mathrm{Cl}$ and $0.4 \mathrm{~g} / \mathrm{L}{ }^{15} \mathrm{~N}$ rich-medium (Isogro ${ }^{15} \mathrm{~N}$, Isotec). The culture was grown at $37{ }^{\circ} \mathrm{C}$ to an $\mathrm{OD}_{600}$ of 0.8 and induced with $0.5 \mathrm{mM}$ IPTG. Incubation was continued for $4 \mathrm{~h}$ at $37{ }^{\circ} \mathrm{C}$ and the culture was then harvested by centrifugation. Purification of recombinant Tau protein was achieved by first heating the sample at $75{ }^{\circ} \mathrm{C}$ for 15 min followed by a cation exchange chromatography. The pure fractions were further buffer exchanged with $50 \mathrm{mM}$ ammonium bicarbonate using a desalting column before lyophilization. Protein concentration was estimated by absorption at $280 \mathrm{~nm}$. Detailed protocols can be found in refs 50 and 51.

PKA Catalytic Subunit Expression and Purification. E. coli BL21 cells were transformed with the pet15b Vector (Addgene plasmid \# 14921) carrying the gene coding for the $\mathrm{N}$-terminally His-tagged PKA catalytic subunit alpha from M. musculus. A $20 \mathrm{~mL}$ preculture in Luria-Bertani (LB) medium containing $100 \mu \mathrm{g} / \mathrm{mL}$ ampicillin was grown overnight at $37{ }^{\circ} \mathrm{C}$ and was used to inoculate a $1 \mathrm{~L}$ culture in $\mathrm{LB}$ medium. The culture was grown at $20^{\circ} \mathrm{C}$ to an $\mathrm{OD}_{600}$ of 0.8 and induced with $0.5 \mathrm{mM}$ IPTG. Incubation was continued for $20 \mathrm{~h}$ at 20 ${ }^{\circ} \mathrm{C}$ and the culture was then harvested by centrifugation. The Histagged PKA catalytic subunit alpha was purified by affinity chromatography using a Ni-NTA column (GE Healthcare, Uppsala, Sweden) and buffer-exchanged with $250 \mathrm{mM}$ potassium phosphate, $0.1 \mathrm{mM}$ DTT $\mathrm{pH} 6.5$ on a desalting column. The protein was aliquoted, flash frozen in liquid nitrogen and stored at $-80{ }^{\circ} \mathrm{C}$.

In Vitro Tau Phosphorylation. Recombinant ${ }^{15} \mathrm{~N}$ labeled Tau protein $(100 \mu \mathrm{M})$ was incubated with $1.5 \mu \mathrm{M}$ recombinant PKA catalytic subunit $\left(\mathrm{PKA}_{\mathrm{c}}\right)$ at $30{ }^{\circ} \mathrm{C}$ for $3 \mathrm{~h}$, in a buffer consisting of 50 $\mathrm{mM}$ Hepes pH 8.0, $5 \mathrm{mM}$ ATP, $12.5 \mathrm{mM} \mathrm{MgCl}, 50 \mathrm{mM} \mathrm{NaCl}, 5 \mathrm{mM}$ DTT, 1 mM EDTA. The reaction was heat-inactivated at $75^{\circ} \mathrm{C}$ for 15 min and the solution was centrifuged in order to eliminate the precipitated $\mathrm{PKA}_{c}$. Buffer exchange with $50 \mathrm{mM}$ ammonium carbonate on a desalting column was performed before lyophilization.

${ }^{15} \mathrm{~N}-{ }^{1} \mathrm{H}$ HSQC Spectroscopy on Full-Length PKA-Phosphorylated Tau (fl-pTau). ${ }^{15} \mathrm{~N}-{ }^{1} \mathrm{H}$ HSQC spectra were acquired in $3 \mathrm{~mm}$ tubes (sample volume $200 \mu \mathrm{L}$ ) using a $900 \mathrm{MHz}$ Bruker Avance spectrometer, equipped with a cryoprobe. Spectra were recorded at $25{ }^{\circ} \mathrm{C}$ in a buffer containing $50 \mathrm{mM}$ Tris $\mathrm{pH} 6.7,30 \mathrm{mM} \mathrm{NaCl}, 2.5$ mM EDTA, $1 \mathrm{mM}$ DTT, EDTA-free protease inhibitor cocktail (Roche, Switzerland) and $10 \%(\mathrm{v} / \mathrm{v}) \mathrm{D}_{2} \mathrm{O}$. The experiments were performed with samples containing $60 \mu \mathrm{M}{ }^{15} \mathrm{~N}$ labeled PKAphosphorylated Tau, $120 \mu \mathrm{M} \mathrm{14-3-3 \zeta}$ and either $360 \mu \mathrm{M}$ or 1200 $\mu \mathrm{M}$ of modified Tau peptide ( 3 and 10-fold excess to $14-3-3 \zeta$ concentration). The experiments were performed on compounds 3.2e, 4.2c-I, and 4.2e-I. The backbone resonance assignments of the Tau protein, including the phosphorylated residues, were previously reported in the literature. ${ }^{42,45}$ The reference for the ${ }^{1} \mathrm{H}$ chemical shift was relative to Trimethylsilyl propionate. Spectra were collected and processed with Topspin 3.5 (Bruker Biospin, Karlsruhe, Germany) and analyzed with Sparky 3.12 (T. D. Goddard and D. G. Kneller, SPARKY 3, University of California, San Francisco).

${ }^{1} \mathrm{H}$ NMR Spectroscopy on 4.2e-I. ${ }^{1} \mathrm{H}$ spectra containing 4.2e-I were acquired in $3 \mathrm{~mm}$ tubes (sample volume $200 \mu \mathrm{L}$ ) using a $600 \mathrm{MHz}$ Bruker Avance I spectrometer equipped with a CPQCI cryoprobe, at $25{ }^{\circ} \mathrm{C}$ in a buffer containing $50 \mathrm{mM}$ Tris $\mathrm{pH} 6.7,30 \mathrm{mM} \mathrm{NaCl}, 2.5$ $\mathrm{mM}$ EDTA and $10 \%(\mathrm{v} / \mathrm{v}) \mathrm{D}_{2} \mathrm{O}$. The experiments were performed with $150 \mu \mathrm{M} 4.2 \mathrm{e}-\mathrm{I}$ alone or in the presence of either $10 \mu \mathrm{M}, 30 \mu \mathrm{M}$, $75 \mu \mathrm{M}$ or $150 \mu \mathrm{M} 14-3-3 \zeta$ or $150 \mu \mathrm{M}$ PKA-phosphorylated Tau. The reference for the ${ }^{1} \mathrm{H}$ chemical shift was relative to Trimethylsilyl propionate. Spectra were collected and processed with Topspin 3.5 (Bruker Biospin, Karlsruhe, Germany).

\section{ASSOCIATED CONTENT}

\section{(S) Supporting Information}

The Supporting Information is available free of charge on the ACS Publications website at DOI: 10.1021/acschemneuro.8b00118.

Synthesis details and characterization data for 1-bromo2-(2-methoxyethoxy)benzene and 1-bromo-3-(2methoxyethoxy)benzene; ${ }^{1} \mathrm{H}$ NMR, ${ }^{13} \mathrm{C}$ NMR, and LCMS or GC-MS spectra for intermediates 2.2, 2.3, 2,4, pyrrolooxazolones $\mathbf{2 . 5 a}-\mathrm{g}$, and benzhydryl pyrrolidine derivatives 2.6a-g; LC-MS data of purified final modified Tau peptides, $3.2 \mathrm{a}-\mathrm{f}$ and $4.2 \mathrm{a}-\mathrm{g}$; thermograms of duplicate ITC measurements of $3.2 \mathrm{a}-\mathrm{f}$ and 4.2a- $\mathrm{g}$ and a summary of the corresponding thermodynamic parameters in table form; data collection and refinement statistics and an in-depth discussion of all crystal structures reported in the paper; supplementary ${ }^{15} \mathrm{~N}-{ }^{1} \mathrm{H}$ HSQC spectra and intensity plots (PDF)

\section{Accession Codes}

Atomic coordinates and structure factors for the crystal structures of $14-3-3 \sigma$ with ligands $3.2 \mathrm{~d}, 3.2 \mathrm{e}, 4.2 \mathrm{~b}, 4.2 \mathrm{c}-\mathrm{I}$, 4.2e-I, 4.2f-I, and 4.2f-II can be accessed using PDB codes 6FI5, 6FI4, 6FBY, 6FAW, 6FAW, 6FAV, and 6FBW, respectively.

\section{AUTHOR INFORMATION}

\section{Corresponding Authors}

*E-mail: 1.milroy@cantab.net.

*E-mail: isabelle.landrieu@univ-lille1.fr.

*E-mail: C.Ottmann@tue.nl.

\section{ORCID}

Sebastian A. Andrei: 0000-0003-2961-8018

Luc Brunsveld: 0000-0001-5675-511X

Christian Ottmann: 0000-0001-7315-0315

Lech-Gustav Milroy: 0000-0003-4601-0936

\section{Author Contributions}

"S.A.A. and F.A.M. contributed equally to this work. The manuscript was written through contributions of all authors. F.A.M. performed synthesis and biochemical studies; S.A.A. and C.O. performed structural characterization and analysis; J.F.N. performed the NMR experiments; I.L., L.B., C.O., and L.-G.M. designed the studies. All authors have given approval to the final version of the manuscript.

\section{Funding}

Funded by The Netherlands Organization for Scientific Resarch via ECHO Grant 717014001, VICI Grant 016150366, Gravity Program 024.001.035, by the Initial Training Network TASPPI, funded by the H2020 Marie Curie Actions of the European Commission under Grant Agreement 675179 and by the LabEx (Laboratory of Excellence) DISTALZ (ANR, ANR-11-LABX009). The NMR facilities were funded by the Nord Region Council, CNRS, Institut Pasteur de Lille, the European Community (ERDF), the French Ministry of Research and the University of Lille and by the CTRL CPER cofunded by the European Union with the European Regional Development Fund (ERDF), by the Hauts de France Regional Council (Contrat No. 17003781), Métropole Européenne de Lille (Contract No. 2016_ESR_05), and French State (Contract No. 2017-R3-CTRL-Phase $\overline{1}$ ).We acknowledge support for the NMR facilities from TGE RMN THC (CNRS, FR-3050) and FRABio (Univ. Lille, CNRS, FR-3688). 


\section{Notes}

The authors declare no competing financial interest.

\section{ACKNOWLEDGMENTS}

Parts of this research were carried out at PETRA III at DESY, a member of the Helmholtz Association (HGF). We would like to thank Anja Burkhardt for assistance in using the P11 beamline and François-Xavier Cantrelle for NMR data acquisition. Some other crystallographic experiments were performed on the X06SA beamline at the Swiss Light Source, Paul Scherrer Institut, Villigen, Switzerland.

\section{REFERENCES}

(1) Cummings, J., Lee, G., Mortsdorf, T., Ritter, A., and Zhong, K. (2017) Alzheimer's Disease Drug Development Pipeline: 2017. Alzheimers Dement. Transl. Res. Clin. Interv. 3 (3), 367-384.

(2) Nelson, P. T., Alafuzoff, I., Bigio, E. H., Bouras, C., Braak, H., Cairns, N. J., Castellani, R. J., Crain, B. J., Davies, P., Del Tredici, K., et al. (2012) Correlation of Alzheimer Disease Neuropathologic Changes with Cognitive Status: A Review of the Literature. J. Neuropathol. Exp. Neurol. 71 (5), 362-381.

(3) Valeur, E., Guéret, S. M., Adihou, H., Gopalakrishnan, R., Lemurell, M., Waldmann, H., Grossmann, T. N., and Plowright, A. T. (2017) New Modalities for Challenging Targets in Drug Discovery. Angew. Chem., Int. Ed. 56 (35), 10294-10323.

(4) Arkin, M. R., and Wells, J. A. (2004) Small-Molecule Inhibitors of Protein-protein Interactions: Progressing towards the Dream. Nat. Rev. Drug Discovery 3 (4), 301-317.

(5) Wells, J. A., and McClendon, C. L. (2007) Reaching for HighHanging Fruit in Drug Discovery at Protein-protein Interfaces. Nature 450 (7172), 1001-1009.

(6) Arkin, M. R., Tang, Y., and Wells, J. A. (2014) Small-Molecule Inhibitors of Protein-Protein Interactions: Progressing toward the Reality. Chem. Biol. 21 (9), 1102-1114.

(7) Milroy, L.-G., Grossmann, T. N., Hennig, S., Brunsveld, L., and Ottmann, C. (2014) Modulators of Protein-Protein Interactions. Chem. Rev. 114 (9), 4695-4748.

(8) Pelay-Gimeno, M., Glas, A., Koch, O., and Grossmann, T. N. (2015) Structure-Based Design of Inhibitors of Protein-Protein Interactions: Mimicking Peptide Binding Epitopes. Angew. Chem., Int. Ed. 54 (31), 8896-8927.

(9) Petta, I., Lievens, S., Libert, C., Tavernier, J., and De Bosscher, K. (2016) Modulation of Protein-Protein Interactions for the Development of Novel Therapeutics. Mol. Ther. 24 (4), 707-718.

(10) Ballatore, C., Brunden, K. R., Trojanowski, J. Q., Lee, V. M.-Y., Smith, A. B., and Huryn, D. M. (2011) Modulation of Protein-Protein Interactions as a Therapeutic Strategy for the Treatment of Neurodegenerative Tauopathies. Curr. Top. Med. Chem. 11 (3), 317-330.

(11) Joo, Y., Schumacher, B., Landrieu, I., Bartel, M., Smet-Nocca, C., Jang, A., Choi, H. S., Jeon, N. L., Chang, K.-A., Kim, H.-S., et al. (2015) Involvement of 14-3-3 in Tubulin Instability and Impaired Axon Development Is Mediated by Tau. FASEB J. 29 (10), 41334144.

(12) Milroy, L.-G., Bartel, M., Henen, M. A., Leysen, S., Adriaans, J. M. C., Brunsveld, L., Landrieu, I., and Ottmann, C. (2015) StabilizerGuided Inhibition of Protein-Protein Interactions. Angew. Chem., Int. Ed. 54 (52), 15720-15724.

(13) Kaplan, A., Ottmann, C., and Fournier, A. E. (2017) 14-3-3 Adaptor Protein-Protein Interactions as Therapeutic Targets for CNS Diseases. Pharmacol. Res. 125 (Pt B), 114-121.

(14) Fu, H., Subramanian, R. R., and Masters, S. C. (2000) 14-3-3 Proteins: Structure, Function, and Regulation. Annu. Rev. Pharmacol. Toxicol. 40 (1), 617-647.

(15) Yaffe, M. B. (2002) How Do 14-3-3 Proteins Work? Gatekeeper Phosphorylation and the Molecular Anvil Hypothesis. FEBS Lett. 513 (1), 53-57.
(16) Aitken, A. (2006) 14-3-3 Proteins: A Historic Overview. Semin. Cancer Biol. 16 (3), 162-172.

(17) Yaffe, M. B., Rittinger, K., Volinia, S., Caron, P. R., Aitken, A., Leffers, H., Gamblin, S. J., Smerdon, S. J., and Cantley, L. C. (1997) The Structural Basis for 14-3-3:Phosphopeptide Binding Specificity. Cell 91 (7), 961-971.

(18) Aghazadeh, Y., and Papadopoulos, V. (2016) The Role of the 14-3-3 Protein Family in Health, Disease, and Drug Development. Drug Discovery Today 21 (2), 278-287.

(19) Freeman, A. K., and Morrison, D. K. (2011) 14-3-3 Proteins: Diverse Functions in Cell Proliferation and Cancer Progression. Semin. Cell Dev. Biol. 22 (7), 681-687.

(20) Kleppe, R., Martinez, A., Døskeland, S. O., and Haavik, J. (2011) The 14-3-3 Proteins in Regulation of Cellular Metabolism. Semin. Cell Dev. Biol. 22 (7), 713-719.

(21) Shimada, T., Fournier, A. E., and Yamagata, K. (2013) Neuroprotective Function of 14-3-3 Proteins in Neurodegeneration. BioMed Res. Int., 564534.

(22) De Vries-van Leeuwen, I. J., da Costa Pereira, D., Flach, K. D., Piersma, S. R., Haase, C., Bier, D., Yalcin, Z., Michalides, R, Feenstra, K. A., Jiménez, C. R., et al. (2013) Interaction of 14-3-3 Proteins with the Estrogen Receptor Alpha F Domain Provides a Drug Target Interface. Proc. Natl. Acad. Sci. U. S. A. 110 (22), 8894-8899.

(23) Anders, C., Higuchi, Y., Koschinsky, K., Bartel, M., Schumacher, B., Thiel, P., Nitta, H., Preisig-Müller, R., Schlichthörl, G., Renigunta, V., et al. (2013) A Semisynthetic Fusicoccane Stabilizes a ProteinProtein Interaction and Enhances the Expression of K+ Channels at the Cell Surface. Chem. Biol. 20 (4), 583-593.

(24) Andrei, S. A., Sijbesma, E., Hann, M., Davis, J., O’Mahony, G., Perry, M. W. D., Karawajczyk, A., Eickhoff, J., Brunsveld, L., Doveston, R. G., et al. (2017) Stabilization of Protein-Protein Interactions in Drug Discovery. Expert Opin. Drug Discovery 12 (9), 925-940.

(25) Stevers, L. M., Sijbesma, E., Botta, M., MacKintosh, C., Obsil, T., Landrieu, I., Cau, Y., Wilson, A. J., Karawajczyk, A., Eickhoff, J., et al. (2017) Modulators of 14-3-3 Protein-Protein Interactions. J. Med. Chem., DOI: 10.1021/acs.jmedchem.7b00574.

(26) Cleveland, D. W., Hwo, S. Y., and Kirschner, M. W. (1977) Purification of Tau, a Microtubule-Associated Protein That Induces Assembly of Microtubules from Purified Tubulin. J. Mol. Biol. 116 (2), 207-225.

(27) Himmler, A., Drechsel, D., Kirschner, M. W., and Martin, D. W. (1989) Tau Consists of a Set of Proteins with Repeated C-Terminal Microtubule-Binding Domains and Variable N-Terminal Domains. Mol. Cell. Biol. 9 (4), 1381-1388.

(28) Lindwall, G., and Cole, R. D. (1984) Phosphorylation Affects the Ability of Tau Protein to Promote Microtubule Assembly. J. Biol. Chem. 259 (8), 5301-5305.

(29) Grundke-Iqbal, I., Iqbal, K., Tung, Y. C., Quinlan, M., Wisniewski, H. M., and Binder, L. I. (1986) Abnormal Phosphorylation of the Microtubule-Associated Protein Tau (Tau) in Alzheimer Cytoskeletal Pathology. Proc. Natl. Acad. Sci. U. S. A. 83 (13), 49134917.

(30) Hashiguchi, M., Sobue, K., and Paudel, H. K. (2000) 14-3-3zeta Is an Effector of Tau Protein Phosphorylation. J. Biol. Chem. 275 (33), 25247-25254.

(31) Yuan, Z., Agarwal-Mawal, A., and Paudel, H. K. (2004) 14-3-3 Binds to and Mediates Phosphorylation of Microtubule-Associated Tau Protein by Ser9-Phosphorylated Glycogen Synthase Kinase 3beta in the Brain. J. Biol. Chem. 279 (25), 26105-26114.

(32) Li, T., and Paudel, H. K. (2007) 14-3-3zeta Facilitates GSK3beta-Catalyzed Tau Phosphorylation in HEK-293 Cells by a Mechanism That Requires Phosphorylation of GSK3beta on Ser9. Neurosci. Lett. 414 (3), 203-208.

(33) Qureshi, H. Y., Li, T., MacDonald, R., Cho, C. M., Leclerc, N.,

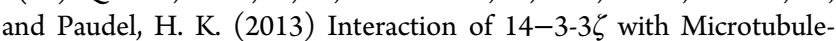
Associated Protein Tau within Alzheimer's Disease Neurofibrillary Tangles. Biochemistry 52 (37), 6445-6455. 
(34) Li, T., and Paudel, H. K. (2016) 14-3-3 $\zeta$ Mediates Tau Aggregation in Human Neuroblastoma M17 Cells. PLoS One 11 (8), e0160635.

(35) Sillen, A., Barbier, P., Landrieu, I., Lefebvre, S., Wieruszeski, J.M., Leroy, A., Peyrot, V., and Lippens, G. (2007) NMR Investigation of the Interaction between the Neuronal Protein Tau and the Microtubules. Biochemistry 46 (11), 3055-3064.

(36) Lou, K., Yao, Y., Hoye, A. T., James, M. J., Cornec, A.-S., Hyde, E., Gay, B., Lee, V. M.-Y., Trojanowski, J. Q., Smith, A. B., et al. (2014) Brain-Penetrant, Orally Bioavailable Microtubule-Stabilizing Small Molecules Are Potential Candidate Therapeutics for Alzheimer's Disease and Related Tauopathies. J. Med. Chem. 57 (14), 6116-6127.

(37) Grüninger, F. (2015) Invited Review: Drug Development for Tauopathies. Neuropathol. Appl. Neurobiol. 41 (1), 81-96.

(38) Dammers, C., Yolcu, D., Kukuk, L., Willbold, D., Pickhardt, M., Mandelkow, E., Horn, A. H. C., Sticht, H., Malhis, M. N., Will, N., et al. (2016) Selection and Characterization of Tau Binding DEnantiomeric Peptides with Potential for Therapy of Alzheimer Disease. PLoS One 11 (12), e0167432.

(39) Molzan, M., Schumacher, B., Ottmann, C., Baljuls, A., Polzien, L., Weyand, M., Thiel, P., Rose, R., Rose, M., Kuhenne, P., et al. (2010) Impaired Binding of 14-3-3 to C-RAF in Noonan Syndrome Suggests New Approaches in Diseases with Increased Ras Signaling. Mol. Cell. Biol. 30 (19), 4698-4711.

(40) Bailey, D. J., O'Hagan, D., and Tavasli, M. (1997) A Short Synthesis of (S)-2-(Diphenylmethyl)Pyrrolidine, a Chiral Solvating Agent for NMR Analysis. Tetrahedron: Asymmetry 8 (1), 149-153.

(41) Stevers, L. M., Lam, C. V., Leysen, S. F. R., Meijer, F. A., van Scheppingen, D. S., de Vries, R. M. J. M., Carlile, G. W., Milroy, L. G., Thomas, D. Y., Brunsveld, L., et al. (2016) Characterization and SmallMolecule Stabilization of the Multisite Tandem Binding between 143-3 and the R Domain of CFTR. Proc. Natl. Acad. Sci. U. S. A. 113 (9), E1152-1161.

(42) Landrieu, I., Lacosse, L., Leroy, A., Wieruszeski, J.-M., Trivelli, X., Sillen, A., Sibille, N., Schwalbe, H., Saxena, K., Langer, T., et al. (2006) NMR Analysis of a Tau Phosphorylation Pattern. J. Am. Chem. Soc. 128 (11), 3575-3583.

(43) Lippens, G., Wieruszeski, J.-M., Leroy, A., Smet, C., Sillen, A., Buée, L., and Landrieu, I. (2004) Proline-Directed Random-Coil Chemical Shift Values as a Tool for the NMR Assignment of the Tau Phosphorylation Sites. ChemBioChem 5 (1), 73-78.

(44) Mukrasch, M. D., Bibow, S., Korukottu, J., Jeganathan, S., Biernat, J., Griesinger, C., Mandelkow, E., and Zweckstetter, M. (2009) Structural Polymorphism of 441-Residue Tau at Single Residue Resolution. PLoS Biol. 7 (2), e1000034.

(45) Smet, C., Leroy, A., Sillen, A., Wieruszeski, J.-M., Landrieu, I., and Lippens, G. (2004) Accepting Its Random Coil Nature Allows a Partial NMR Assignment of the Neuronal Tau Protein. ChemBioChem 5 (12), 1639-1646.

(46) Powell, H. R., Johnson, O., and Leslie, A. G. W. (2013) Autoindexing Diffraction Images with IMosflm. Acta Crystallogr., Sect. D: Biol. Crystallogr. 69 (7), 1195-1203.

(47) McCoy, A. J. (2007) Solving Structures of Protein Complexes by Molecular Replacement with. Acta Crystallogr., Sect. D: Biol. Crystallogr. 63 (1), 32-41.

(48) Adams, P. D., Grosse-Kunstleve, R. W., Hung, L. W., Ioerger, T. R., McCoy, A. J., Moriarty, N. W., Read, R. J., Sacchettini, J. C., Sauter, N. K., and Terwilliger, T. C. (2002) PHENIX: Building New Software for Automated Crystallographic Structure Determination. Acta Crystallogr., Sect. D: Biol. Crystallogr. 58 (11), 1948-1954.

(49) Emsley, P., Lohkamp, B., Scott, W. G., and Cowtan, K. (2010) Features and Development of Coot. Acta Crystallogr., Sect. D: Biol. Crystallogr. 66 (4), 486-501.

(50) Danis, C., Despres, C., Bessa, L. M., Malki, I., Merzougui, H., Huvent, I., Qi, H., Lippens, G., Cantrelle, F.-X., Schneider, R., et al. (2016) Nuclear Magnetic Resonance Spectroscopy for the Identification of Multiple Phosphorylations of Intrinsically Disordered Proteins. J. Visualized Exp., 118.
(51) Qi, H., Despres, C., Prabakaran, S., Cantrelle, F.-X., Chambraud, B., Gunawardena, J., Lippens, G., Smet-Nocca, C., and Landrieu, I. (2017) The Study of Posttranslational Modifications of Tau Protein by Nuclear Magnetic Resonance Spectroscopy: Phosphorylation of Tau Protein by ERK2 Recombinant Kinase and Rat Brain Extract, and Acetylation by Recombinant Creb-Binding Protein. Methods Mol. Biol. 1523, 179-213. 